\title{
Understanding the Tribological Behavior of Graded (Cr,AI)N + Mo:S in Fluid-Free Friction Regime
}

\author{
K. Bobzin ${ }^{1}$ (D) C. Kalscheuer ${ }^{1} \cdot$ M. Thiex ${ }^{1}$ (D)
}

Received: 26 July 2021 / Accepted: 20 October 2021 / Published online: 3 November 2021

(c) The Author(s) 2021

\begin{abstract}
Components running in fluid-free friction regimes are exposed to harsh conditions leading to increased friction and wear. Thereby, the use of the solid lubricant molybdenum disulfide $\left(\mathrm{MoS}_{2}\right)$ via lacquers, powders or physical vapor deposition (PVD) coatings enables a friction and wear reduction. However, the tribological performance is limited to low mechanical loads. A promising coating concept already proven for high mechanical loads is the incorporation of the triboactive elements Mo and $\mathrm{S}$ in wear resistant hard nitride $(\mathrm{Cr}, \mathrm{Al}) \mathrm{N}$ matrix. In this study the supply mechanism and transfer of the tribofilm build out of the toplayer of the triboactive coating graded $(\mathrm{Cr}, \mathrm{Al}) \mathrm{N}+\mathrm{Mo}: \mathrm{S}$ under high mechanical loads at humid air were analyzed. Here, the chemical composition of the tribofilm was determined by a combination of Raman spectroscopy and X-ray photoelectron spectroscopy (XPS) and correlated with tribological analysis. The results prove a friction and wear reduction independent of Hertzian pressure in the area of $400 \mathrm{MPa} \leq p_{\mathrm{H}} \leq 1300 \mathrm{MPa}$ due to the formation of a MoS $\mathrm{M}_{2}$ and molybdenum oxide $\mathrm{Mo}_{\mathrm{x}} \mathrm{O}_{\mathrm{y}}$ containing tribofilm, whereby the share of $\mathrm{Mo}_{\mathrm{x}} \mathrm{O}_{\mathrm{y}}$ dominates compared to $\mathrm{MoS}_{2}$. Based on the results the understanding of the effect of the $\mathrm{MoS}_{2}+\mathrm{Mo}_{\mathrm{x}} \mathrm{O}_{\mathrm{y}}$ containing tribofilm on the tribological behavior is increased.
\end{abstract}

Keywords Pin on disc $\cdot \mathrm{MoS}_{2} \cdot$ Tribofilm $\cdot$ Transfer mechanism $\cdot$ Third body $\cdot(\mathrm{Cr}, \mathrm{Al}) \mathrm{N}+\mathrm{Mo}: \mathrm{S}$

\section{Introduction}

The application of solid lubricants in tribological systems under fluid-free friction regimes enables a friction and wear reduction, through the separation of contacting surfaces and low shearing forces. Erdemir divided solid lubricants into the five different groups metallic soaps and phosphates, polymers, oxide and fluoride compounds, soft metals and compounds with layered lattice structure [1]. A typical representative for the latter group is the transition metal dichalcogenides (TMD) molybdenum disulfide $\left(\mathrm{MoS}_{2}\right)$ with a hexagonal lamellar crystal structure possessing strong covalent bonds within the planes and weak van der Waals forces between the planes. The use of $\mathrm{MoS}_{2}$ in technical applications can be realized by physical vapor deposition (PVD) coatings, powders or via lacquers. Analysis of lacquers and PVD coatings in tribological contacts in fluid-free friction regime showed an improved performance compared to the

M. Thiex

thiex@iot.rwth-aachen.de

1 Surface Engineering Institute (IOT), RWTH Aachen University, Kackertstraße 15, 52072 Aachen, Germany contact of uncoated steel as shown in [2,3]. Erdemir reports a preferred use of PVD coatings in technical applications due to their strong bonding, dense microstructure, uniform thickness and improved wear life [1]. In addition, a higher variety in the chemical compositions, structure ranging from amorphous to sub-stoichiometric, deposition at room temperature and diversity of coating architectures by the PVD coating process lead to further advantages versus the use of lacquers and powders.

\section{1 $\mathrm{MoS}_{2}$ Coating Concepts for Fluid-Free Running Applications}

Different $\mathrm{MoS}_{2}$ coating architecture concepts are discussed, compared and generally summarized in Fig. 1. Studies of Wahl et al. and Gradt et al. report high wear rates in tribological contacts under fluid-free friction regimes by the application of non-modified $\mathrm{MoS}_{2}$ PVD coatings [4, 5]. A study of $\mathrm{MoS}_{2}$ PVD coatings by Spalvins shows, that changes of the deposition parameters like cathode power, chamber pressure and substrate temperature affect the structure, adhesion and stoichiometry of the coatings and lead to differences in the tribological behavior, so that the coatings can be tailored 
Fig. 1 Schematic representation of different $\mathrm{MoS}_{2}$ coating architectures and comparison of advantages and disadvantages with regard to tribological use

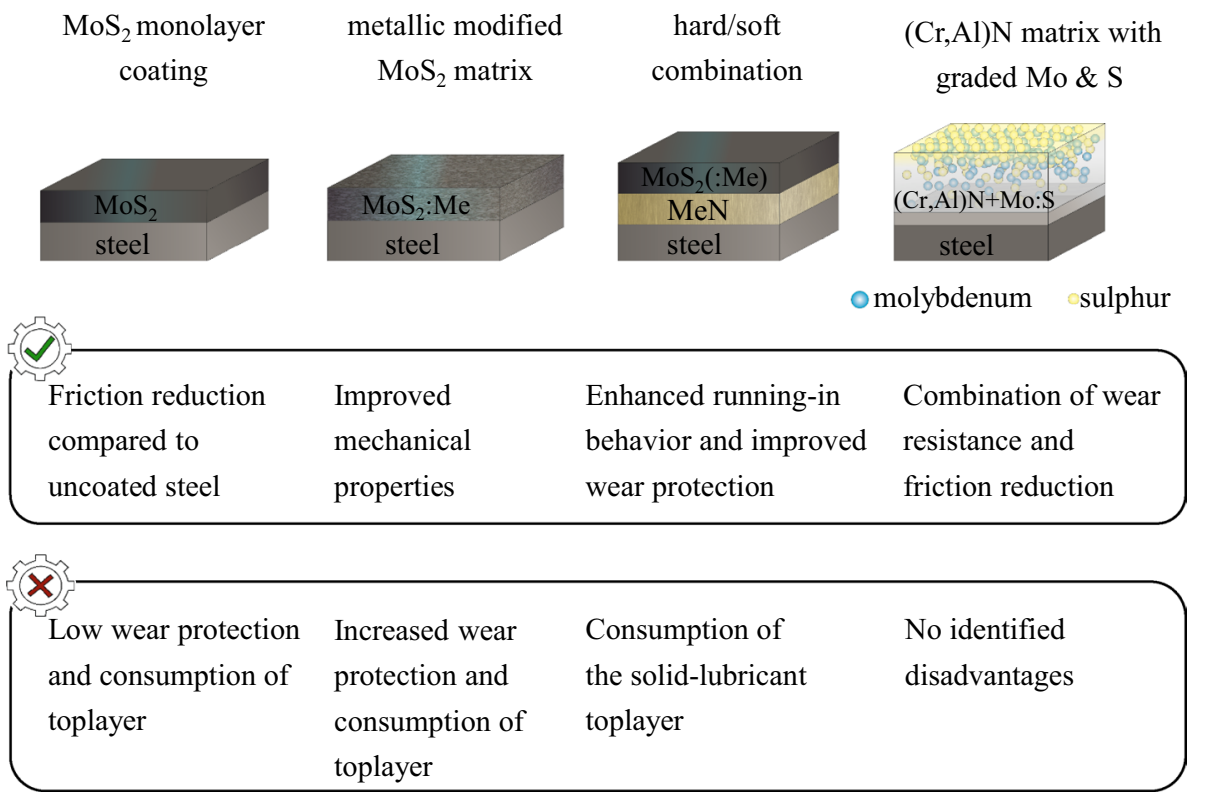

according to the requirements of the technical application [6].

One possibility is to modify the $\mathrm{MoS}_{2}$ coatings with metals such as $\mathrm{Ti}, \mathrm{Cr}, \mathrm{Al}$ or non-metals such as $\mathrm{C}$ and $\mathrm{N}$ to increase the tribological performance. Stupp analyzed the modification of $\mathrm{MoS}_{2}$ coatings with different metals and there effect on the tribological behavior [7]. The findings prove, that among others $\mathrm{Cr}, \mathrm{Co}, \mathrm{Ni}, \mathrm{Au}$ and $\mathrm{Ta}$ with a share below $\mathrm{x}_{\mathrm{Me}}<10 \%$ in $\mathrm{MoS}_{2}$ lead to a stable frictional curve progression compared to a non-modified $\mathrm{MoS}_{2}$ coating under fluid-free friction regime. Moreover, Stupp predicted that the addition of metals in $\mathrm{MoS}_{2}$ coatings favors the crystal growth and stabilizes the coating structure. Spalvins extended this thesis on the basis of his study by a schematic illustration, in which the packing density of the columnar structure increases significantly by the modification of $\mathrm{MoS}_{2}$ coating with $\mathrm{Au}$ and thus also the resistance against delamination due to fraction [8]. The study of Simmonds et al. showed that the modification of $\mathrm{MoS}_{2}$ with $\mathrm{Cr}$ or $\mathrm{Ti}$ increases the wear protection but also the wear of the uncoated counter body. In contrast thereto, the modification of $\mathrm{MoS}_{2}$ with $\mathrm{Au}$ only enables a reduced wear protection of the coated sample compared to the modification with $\mathrm{Cr}$ or Ti [9]. However, the modification of $\mathrm{MoS}_{2}$ with $\mathrm{Cr}$ leads to a stabilized frictional behavior and increased hardness. Tedstone et al. analyzed the origin of the increased hardness by modifying $\mathrm{MoS}_{2}$ coatings with $\mathrm{Cr}$ and showed that higher $\mathrm{Cr}$ shares lead to an increasing brittle failure mode [10]. The reason was given by the increasing compressive stress within the $\mathrm{Cr}$ modified $\mathrm{MoS}_{2}$ coating. Teer et al. proved an enhanced tribological performance with low friction and high wear resistance by using the commercially available MoST ${ }^{\circledR}$ coating (Teer Coatings Ltd., Droitwich, United
Kingdom), which is a titanium modified $\mathrm{MoS}_{2}$ multilayer coating [11]. Among other things, this coating is offered for dry machining of steels as well as vacuum and aerospace applications. Further analyses of Teer showed, that the positive effect of MoST® on the tribological behavior is limited by a titanium share of $x_{\mathrm{Me}}<18 \%$ [12]. Furthermore, the analyses of Teer lead to the assumption that Ti is embedded between the neighboring sulfur planes. Based on this assumption Kim et al. predicted that the positive effect of Ti modified $\mathrm{MoS}_{2}$ coatings on the wear protection is caused by in situ build titanium dioxid $\mathrm{TiO}_{2}$ [13]. This leads to the conclusion that titanium is embedded in an unbonded state in the coating matrix.

Carrera et al. pursued another approach, whereby a $\mathrm{Ti}$ modified $\mathrm{MoS}_{2}$ coating is supported by a $\mathrm{CrN}$ interlayer leading to a hard/soft coating architecture $\mathrm{CrN} / \mathrm{MoS}_{2}(\mathrm{Ti})$ [14]. The same coating architecture composed of a TiN interlayer and a $\mathrm{MoS}_{2}$ toplayer was analyzed by Ma et al. [15]. Both studies show that the combination of a hard coating matrix and a soft toplayer improves the tribological behavior. The disadvantage of the so far presented coating concepts is that the supply of the solid lubricant is limited by the consumption of the toplayer.

Gilmore et al. deviate from these concepts by embedding sub-stoichiometric $\mathrm{MoS}_{x}$ into a TiN coating matrix, enabling the possible application in highly loaded tribological contacts like cutting tools for dry machining [16]. Based on the structural analysis of the TiN-MoS 2 coatings by scanning electron microscopy (SEM), Gilmore et al. predicted that $\mathrm{MoS}_{2}$ is not incorporated in the TiN structure but located between the TiN grains. Transmission electron microscopy (TEM) analysis of TiN-MoS ${ }_{2}$ coatings by Strapasson et al. disprove the theory of Gilmore et al. and lead to the 
conclusion that $\mathrm{MoS}_{2}$ clusters are embedded in the TiN coating matrix [17]. Moreover, the study of Kim et al. showed that by increasing the $\mathrm{MoS}_{2}$ share in a $\mathrm{CrN}$ coating matrix leads to a reduction of the crystalline structure [18]. Bae et al. analyzed TiN-MoS $\mathrm{S}_{2}$ coatings against a $\mathrm{Si}_{3} \mathrm{~N}_{4}$ counter body under dry friction regime by increasing the temperature in the range of $-20{ }^{\circ} \mathrm{C} \leq \mathrm{T} \leq 700{ }^{\circ} \mathrm{C}$ [19]. Thereby a low coefficients of friction $\mu \approx 0.1$ till $T=300{ }^{\circ} \mathrm{C}$ was proven, which can be justified by the formation $\mathrm{MoS}_{2}$ and the $\mathrm{MoO}_{3}$. Further temperature rises to $T=400{ }^{\circ} \mathrm{C}$ lead to higher at $0.6 \leq \mu \leq 0.7$. A friction reduction to $\mu \approx 0.3$ is measured again, when the temperature reaches $T=700 \mathrm{C}$, whereby the tribological behavior is dominated by the formation of molybdenum trioxide $\mathrm{MoO}_{3}$. An explanation regarding the friction reduction based on the structure of oxides at elevated temperatures of Mo, Ti, W, etc. was given by Erdemir in [20]. An alternative coating concept for the use of $\mathrm{MoS}_{2}$ is the incorporation of Mo and $\mathrm{S}$ into a hard coating $(\mathrm{Cr}, \mathrm{Al})$ $\mathrm{N}$ matrix with graded coating architecture [21]. Thereby, the $(\mathrm{Cr}, \mathrm{Al}) \mathrm{N}$ serves as wear resistant matrix and the shares of solid lubricant-forming elements Mo and S are gradually increased towards the toplayer. Tribological analyses in fluid-free friction regime prove a significant friction and wear reduction compared to an uncoated steel/steel contact. Also first analysis by means of Raman spectroscopy of the build tribofilm supplied form the toplayer of the graded $(\mathrm{Cr}, \mathrm{Al}) \mathrm{N}+\mathrm{Mo}$ :S coating and the transferred tribofilm were conducted. However, to gain a deeper understanding, further analysis has to be proceeded to understand the tribological behavior of the tribofilm and the effect on friction and wear.

\subsection{Dependency of the Tribological Behavior on the Tribofilm Affected by the Formation of Oxides}

In general, the coating supplies the solid lubricant out of the toplayer as a result of wear and friction. The relevance of the tribofilm increases significantly in fluid-free friction regimes where the separation of the contact surfaces by a base oil is not provided and enables, depending on the chemical composition, a wear protection and/or a friction reduction. Scharf et al. named two functions of tribofilms in tribological contacts [22]. The first is to separate the contacting surfaces from each other and thus prevent direct contact of the surface asperities. The second function influences the frictional behavior, which describes a low shearing of the tribofilm near to the contacting surfaces. Another important factor depends on whether the solid lubricant supply is extrinsic or intrinsic. In case of an intrinsic solid lubricant supply, a sufficient adhesion of the tribofilm on the contacting surface enables a higher performance duration of the tribological system. A partial local detachment of the tribofilm leads to an increase of friction.
Basically, the friction reduction of $\mathrm{MoS}_{2}$ is driven by the presence of the (0001) orientated basal planes possessing a low shearing strength. However, for use in fluid-free friction regimes under air, tribofilm formation is significantly affected by the presence of oxygen, enabling the formation of $\mathrm{MoO}_{3}$. Tribological analysis of Donnet et al. prove an average coefficient of friction (CoF) of $\mu=0.002$ under ultra-high vacuum (UHV) conditions by using a $\mathrm{MoS}_{2}$ PVD coating tested against uncoated $100 \mathrm{Cr} 6$, which is in the area of superlubricity [23]. In contrast thereto the CoF under humid air in fluid-free friction regime increased to $\mu=0.150$. The authors correlated these results with the calculated shear strengths between tribofilm and coating with $\sigma=0.7 \mathrm{MPa}$ under UHV and $\sigma=56.0 \mathrm{MPa}$ at atmosphere. It was concluded, that with an increasing share of $\mathrm{MoO}_{3}$ in relation to $\mathrm{MoS}_{2}$, the oxide displaces the basal planes and thus leads to an increase of the CoF. In addition, the physisorption of water has to be taken into account. High friction and wear rates as a result of the tribological analysis of $\mathrm{MoS}_{2}$ coatings under air with a relative humidity $\mathrm{RH}=35 \%$ at $T=22{ }^{\circ} \mathrm{C}$ and an initial Hertzian pressure $p_{\mathrm{H}}=200 \mathrm{MPa}$ of Kubart et al. were also justified on the negative effect of water adsorption [24]. The minimal $\mathrm{CoF}$ and wear rates were reached at $T=100{ }^{\circ} \mathrm{C}$, due to the almost neglectable water adsorption in contrast to $T=22{ }^{\circ} \mathrm{C}$. Further temperature rises till $T=400{ }^{\circ} \mathrm{C}$ lead to higher $\mathrm{CoF}$, wear rates and operational limits of the $\mathrm{MoS}_{2}$ coating, which can be reasoned by increasing oxidation. Khare et al. set up a hypothesis that defines $T=100{ }^{\circ} \mathrm{C}$ as a transition temperature of $\mathrm{MoS}_{2}$ under humid air at $p_{\mathrm{H}}=100 \mathrm{MPa}$ [25]. Below this temperature water adsorption impedes the inter-lamellar shear of $\mathrm{MoS}_{2}$ leading to increased friction. Above $T=100{ }^{\circ} \mathrm{C}$ the oxidation of $\mathrm{MoS}_{2}$, initiated by the tribological load and/ or the over-/sub- stoichiometric composition of Mo and $\mathrm{S}$ in the coating enabling the oxidation of unbonded Mo, becomes the decisive factor with regard to friction and wear. Nevertheless, results from Lince et al. show high potential of $\mathrm{MoS}_{2-x} \mathrm{O}_{x}$ bindings for use in highly loaded tribological contacts [26]. Fleischauer et al. summarized the different findings from the literature regarding the dependency of the $\mathrm{CoF}$ on the content of oxygen in the coatings in a schematic diagram [27]. Therein it is shown, that as soon as the share of $\mathrm{MoS}_{2-x} \mathrm{O}_{x}$ exceeds $10 \%$ the $\mathrm{CoF}$ can be reduced, although not to the level of $\mathrm{MoS}_{2}$. This conclusion can be transferred to the effect of the chemical composition of the tribofilm on the tribological behavior, whereby a friction reduction can also be achieved despite the presence of oxides in the $\mathrm{MoS}_{2}$ tribofilm.

However, the presented publications do not consider the chemical composition of the tribofilm and its influence on the tribological behavior in depth. Moreover, several authors assume $\mathrm{MoS}_{2}$ coatings with a stoichiometric composition of Mo and S, which generally does not have to be the case. 
Chemical analysis of the toplayer of the in this study analyzed graded $(\mathrm{Cr}, \mathrm{Al}) \mathrm{N}+\mathrm{Mo}: \mathrm{S}$ by means of X-ray microanalysis (EPMA) show a sub-stoichiometric ratio of Mo and $\mathrm{S}$ [21]. Another example are $(\mathrm{Cr}, \mathrm{Al}) \mathrm{N}+\mathrm{Mo}: \mathrm{S}$ coatings for dry metal forming [28]. Therefore further research regarding the supply mechanism of $(\mathrm{Cr}, \mathrm{Al}) \mathrm{N}+\mathrm{Mo}: \mathrm{S}$ and the transferred tribofilm is necessary to understand the tribological behavior in fluid-free friction regime at humid air.

\section{Experimental Details}

\subsection{Coating Deposition}

The Mo and $\mathrm{S}$ containing $(\mathrm{Cr}, \mathrm{Al}) \mathrm{N}+\mathrm{Mo}: \mathrm{S}$ coating was deposited in an industrial scale coating machine CC800/9 HPPMS, CemeCon AG, Wuerselen, Germany, by developing a low temperature coating process $T \leq 270{ }^{\circ} \mathrm{C}$ shown in [21]. Regardless of the exceeding of the annealing temperature of case-hardened $16 \mathrm{MnCr} 5 \mathrm{E}$ in the area $150{ }^{\circ} \mathrm{C} \leq T \leq 200{ }^{\circ} \mathrm{C}$ the hardness loss of $1 \mathrm{HRC} \leq H \leq 3 \mathrm{HRC}$ is situated in the range of the standard deviation of the case-hardening process $H=(60 \pm 2)$ HRC. The coating unit was equipped with four direct current magnetron sputtering (dcMS) cathodes and two high power pulsed magnetron sputtering (HPPMS) cathodes. The arrangement of the cathodes and the layout of the deposition chamber are depicted in Fig. 2a).

For the deposition of the $(\mathrm{Cr}, \mathrm{Al}) \mathrm{N}+\mathrm{Mo}: \mathrm{S}$ coatings $\mathrm{Al}$ plugged $\mathrm{Cr}$ targets (purity $\mathrm{Cr} 99.95 \%$, purity $\mathrm{Al} 99.5 \%$ ), a Cr plugged Al target (purity Al 99.5\%, purity $\mathrm{Cr} 99.5 \%$ ), and a $\mathrm{MoS}_{2}$ target (purity 99.5\%), were used. The notation
CrAl20 refers to a $\mathrm{Cr}$-based target with $20 \mathrm{Al}$ plugs. Furthermore, $\mathrm{AlCr} 30$ represents an Al-based target with $30 \mathrm{Cr}$ plugs. The dimensions of the targets were $500 \mathrm{~mm} \times 88 \mathrm{~mm}$ and the diameter of the $\mathrm{Al}$ or $\mathrm{Cr}$ plugs were approximately $\varnothing \approx 15 \mathrm{~mm}$, Fig. 1b). The exact target configuration used for the coating deposition is shown in Table 1.

The coating was deposited on case-hardened $16 \mathrm{MnCr} 5 \mathrm{E}$ steel samples $(\varnothing=25 \mathrm{~mm}, H=8 \mathrm{~mm})$ polished to a roughness $\mathrm{Ra}=0.02 \mu \mathrm{m}$. The case-hardened steel 16MnCr5E had a surface hardness of $H=(60 \pm 2)$ HRC with a casehardening depth $d_{\mathrm{c}}=1 \mathrm{~mm}$, to ensure a sufficient load carrying capacity for the $(\mathrm{Cr}, \mathrm{Al}) \mathrm{N}+\mathrm{Mo}$ :S coatings. The process parameters of the coating process are summarized in Table 2.

\subsection{Tribological Analysis}

The samples were tested under pure sliding conditions in a pin-on-disk (PoD) tribometer, CSM Instruments, Peseux, Switzerland. A schematic representation of the PoD testing is shown in Fig. 3. Tribological tests were conducted under dry-running conditions in a coating/steel contact at different initial Hertzian pressures $p_{\mathrm{H}}=\{400 ; 600 ; 800 ; 1300\} \mathrm{MPa}$ calculated based on basic part and counter part properties. Therefore, the normal force was adjusted to $F_{\mathrm{N}}=0.5 \mathrm{~N}$ for $p_{\mathrm{H}}=400 \mathrm{MPa}$ and $F_{\mathrm{N}}=2 \mathrm{~N}$ for $p_{\mathrm{H}}=600 \mathrm{MPa}$ by using an uncoated $\varnothing=10 \mathrm{~mm}$ diameter $100 \mathrm{Cr} 6$ ball. With regard to the higher Hertzian loads, uncoated 100Cr6 balls with a diameter of to $\varnothing=6 \mathrm{~mm}$ were chosen at a normal force of $F_{\mathrm{N}}=2 \mathrm{~N}$ for $p_{\mathrm{H}}=800 \mathrm{MPa}$ and $F_{\mathrm{N}}=8 \mathrm{~N}$ for $p_{\mathrm{H}}=1300 \mathrm{MPa}$. The further parameters relative velocity $v_{\text {rel }}=0.1 \mathrm{~m} / \mathrm{s}$, radius
Fig. 2 Schematic representation of the industrial coating unit CC800/9 HPPMS (a) coating unit

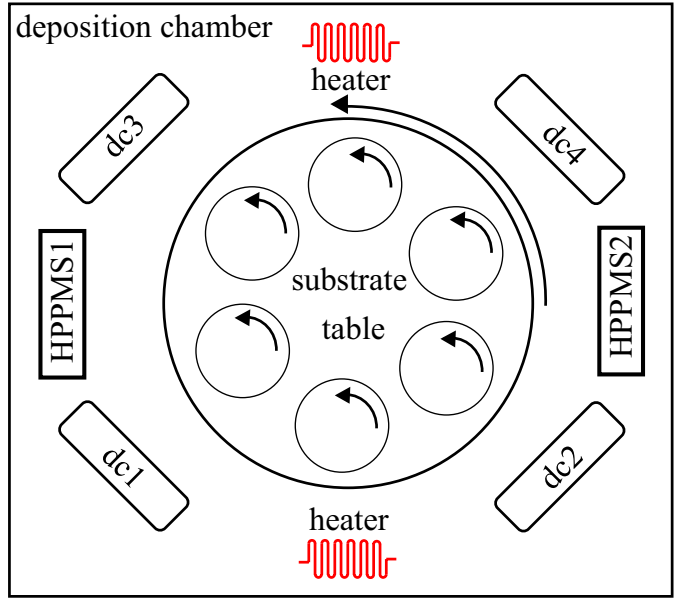

(b) target

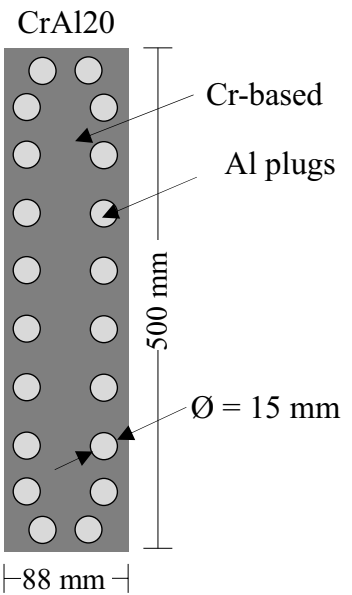

Table 1 Target configuration for the deposition of the graded $(\mathrm{Cr}, \mathrm{Al}) \mathrm{N}+\mathrm{Mo}: \mathrm{S}$ coating

\begin{tabular}{lllllll}
\hline Cathode & HPPMS1 & HPPMS2 & $\mathrm{dc} 1$ & $\mathrm{dc} 2$ & $\mathrm{dc} 3$ & $\mathrm{dc} 4$ \\
\hline target & $\mathrm{CrAl20}$ & $\mathrm{CrAl20}$ & $\mathrm{AlCr} 30$ & $\mathrm{MoS}_{2}$ & $\mathrm{MoS}_{2}$ & $\mathrm{CrAl20}$ \\
\hline
\end{tabular}


Table 2 Process parameters of graded $(\mathrm{Cr}, \mathrm{Al}) \mathrm{N}+\mathrm{Mo}: \mathrm{S}$ coatings [21]

\begin{tabular}{lll}
\hline Process phase & Process parameter [unit] & $(\mathrm{Cr}, \mathrm{Al}) \mathrm{N}+\mathrm{Mo}: \mathrm{S}$ \\
\hline $\begin{array}{l}\text { Interlayer/intermediate } \\
\text { layer }\end{array}$ & Pulsed bias voltage, $U_{\mathrm{B}, \mathrm{HPPMS}}[\mathrm{V}]$ & -150 to $(-75)$ \\
& Nitrogen pressure controlled, $\mathrm{p}_{\mathrm{N} 2}[\mathrm{mPa}]$ & 500 \\
& Argon gas flow, Q(Ar) $[\mathrm{sccm}]$ & 200 \\
& Ramped cathode power, $P_{\mathrm{dc}}(\mathrm{CrAl} 20, \mathrm{AlCr} 30)[\mathrm{W}]$ & $800-0$ \\
& Ramped cathode power, $P_{\mathrm{dc}}\left(\mathrm{MoS}_{2}\right)[\mathrm{W}]$ & $800-3800$ \\
& Ramped cathode power, $P_{\mathrm{HPPMS}}[\mathrm{W}]$ & $4500-2000$ \\
& Pulse-on-time, $t[\mu \mathrm{s}]$ & 40 \\
& Pulse frequency, $f[\mathrm{~Hz}]$ & 500 \\
& Process time, $t_{\mathrm{p}}[\mathrm{s}]$ & 6845 \\
& Nitrogen gas flow, $\mathrm{Q}\left(\mathrm{N}_{2}\right)[\mathrm{sccm}]$ & $150-100$ \\
Toplayer & Argon pressure controlled, $p_{\mathrm{Ar}}[\mathrm{mPa}]$ & 600 \\
& Cathode power, $P_{\mathrm{dc}}\left(\mathrm{MoS}{ }_{2}\right)[\mathrm{W}]$ & 3800 \\
& Cathode power, $P_{\mathrm{HPPMS}}[\mathrm{W}]$ & 2000 \\
& Process time, $t_{\mathrm{p}}[\mathrm{s}]$ & 920 \\
\hline
\end{tabular}

Fig. 3 Schematic representation of the PoD testing

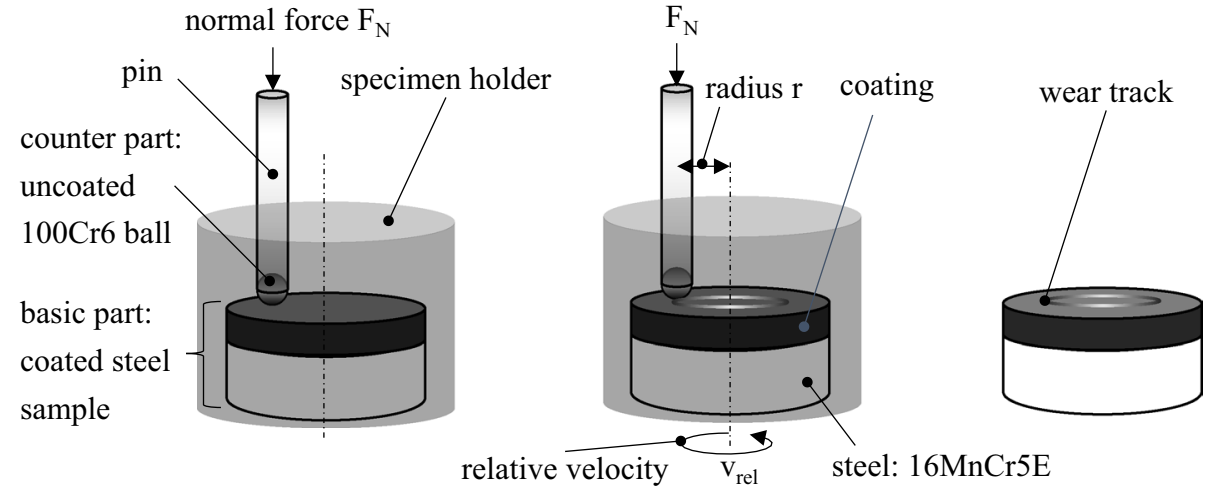

$r=2.5 \mathrm{~mm}$, distance $s=200 \mathrm{~m}$ and $s=400 \mathrm{~m}$, room temperature $T=(20 \pm 3){ }^{\circ} \mathrm{C}$ and relative humidity $\varphi \approx(45 \pm 5) \%$, were kept constant. A repetition of each test was not conducted, since the focus was set on the tribofilm. A comprehensive tribological analysis of the coefficients of friction and the wear volumes of basic parts and counter part was already presented in [21]. Topographical and wear analysis of the wear tracks on the basic parts and wear areas on the counter parts were conducted after tribological testing by means of confocal laser scanning microscopy (CLSM), Keyence VK X210, Tokyo, Japan.

\subsection{Chemical Analysis of the Tribofilm}

A systematic chemical analysis of tribofilm on the wear tracks of basic parts and counter parts was conducted by means of Raman spectroscopy and X-ray photoelectron spectroscopy (XPS) analysis. At first, the wear tracks at basic part and counter part were analyzed by means of CLSM, exemplary shown in Fig. 4. Here, four points at the basic part $a, b, c$ and $d$ and four points at the counter part 1,2, 3 and 4 were defined for the analysis by Raman spectroscopy.
Point measurements with five repetitions were conducted at every point by using Raman spectrometer, Renishaw InVia Reflex, Renishaw GmbH, Pliezhausen, Germany. The parameters for analysis are shown in Table 3. A representative spectrum out of the five measurements was chosen for evaluation. Furthermore, a reference spectrum of the asdeposited basic part and uncoated counter part were taken. All spectra were evaluated individually by using the software Wire® 5.2, Renishaw plc, Wotton-under-Edge, United Kingdom. Thereby the spectra were evaluated section by section of the Raman shift by a combined Gaussian and Lorentzian fitting. Due to the compact presentation form in ****. 9, $10,11,12$, some of the identified peaks appear smaller than they do in the single spectrum. However, the comprehensive compact presentation allows a better overview of the chemical composition of the tribofilm.

Moreover, X-ray photoelectron spectroscopy (XPS) analysis on the coated basic part and the uncoated counter part after $p_{\mathrm{H}}=1300 \mathrm{MPa}$ and $s=200 \mathrm{~m}$ were proceeded to evaluate the binding structure of the tribofilms and correlate the results to the findings by means of Raman spectroscopy. The XPS analysis were conducted at Natural and Medical 
Fig. 4 Topography images of the wear track on the basic part and counter part after tribological analysis at $s=200 \mathrm{~m}$ and $p_{\mathrm{H}}=1300 \mathrm{MPa}$

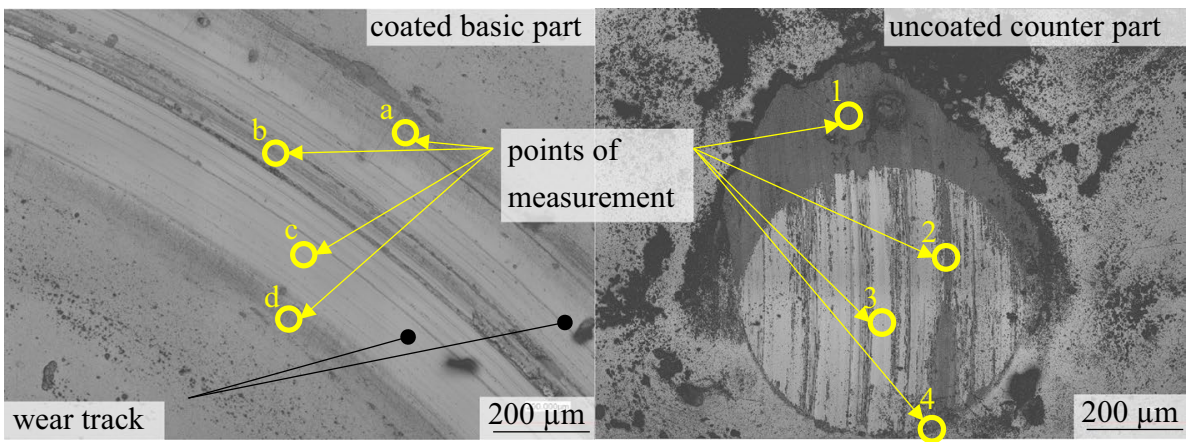

Table 3 Raman measurement parameters for chemical analysis of the wear tracks of basic part and counter part

\begin{tabular}{lll}
\hline Parameter & Coated basic part & $\begin{array}{l}\text { Uncoated } \\
\text { counter } \\
\text { part }\end{array}$ \\
\hline Wavelength $\lambda$ in nm & 532 & 532 \\
Laser power $P_{\mathrm{L}}$ in mW & 0.6 & 1.2 \\
Accumulations $\mathrm{N}$ & 4 & 4 \\
Exposure time $t_{\mathrm{E}}$ in s & 20 & 15 \\
\hline
\end{tabular}

Sciences Institute (NMI) at the University of Tübingen, Tübingen, Germany, with an argon cluster gun, which enables a sensitive characterization to avoid damaging the binding structure. The Quantera Dual Beam charge neutralizer system was used on all specimens. Spectra were analyzed using Physical Electronics (PHI) MultiPak software ${ }^{\circledR}$, Physical Electronics, Inc. (PHI), Chanhassen, Minnesota, USA. The peak evaluation of the software is based on Moulder et al. [29]. High resolution analyses were carried out with an analysis area of $\varnothing=100 \mu \mathrm{m}$ and a pass energy of $E=55 \mathrm{eV}$ at the positions $b$ and 1, Fig. 4. Spectra have been charge corrected to the main line of the carbon $1 \mathrm{~s}$ spectrum (adventitious carbon) set to $E=284.8 \mathrm{eV}$. Furthermore, the spectra were analyzed using a Shirley Background with $80 \%$ Gaussian and 20\% Lorentzian line shape and an area lock ratio of 1:2 for $p$ levels and 2:3 for $d$ level. Doublet Separation of $E=3.13 \mathrm{eV}$ was used for the analysis of the Mo $3 \mathrm{~d}$ line and $E=1.18 \mathrm{eV}$ for the S 2p line. XPS spectra were taken in three different information depths surface before sputtering, $t=5 \mathrm{~min}$ sputtering time and $t=120 \mathrm{~min}$ sputtering time.

\section{Results and Discussion}

\subsection{Tribological Analysis}

The results of tribological analysis of graded $(\mathrm{Cr}, \mathrm{Al})$ $\mathrm{N}+\mathrm{Mo}: \mathrm{S}$ as well as of $16 \mathrm{MnCr} 5 \mathrm{E}$ against uncoated 100Cr6 counter balls at a Hertzian pressure of $p_{\mathrm{H}}=1300 \mathrm{MPa}$ for $s=1000 \mathrm{~m}, v=0.1 \mathrm{~m} / \mathrm{s}$ at $T=20^{\circ} \mathrm{C}$ under fluid-free friction regime conditions are shown in Fig. 5. Basically, a significant friction reduction of $-55 \%$ could be achieved by using a graded $(\mathrm{Cr}, \mathrm{Al}) \mathrm{N}+\mathrm{Mo}: \mathrm{S}$ coating compared to uncoated
Fig. $5 \mathrm{CoF}$ of graded $(\mathrm{Cr}, \mathrm{Al})$ $\mathrm{N}+\mathrm{Mo}: \mathrm{S} / 100 \mathrm{Cr} 6$ and $16 \mathrm{MnCr} 5 \mathrm{E} / 100 \mathrm{Cr} 6$ shown in [21]

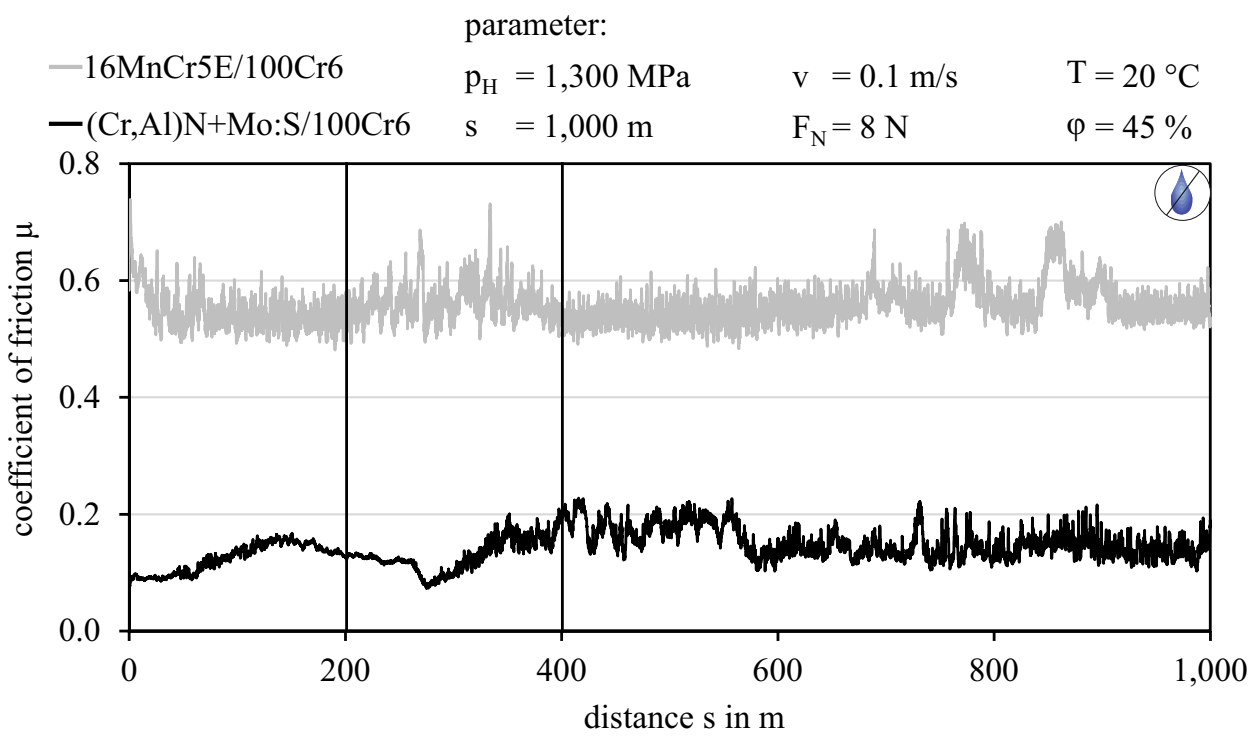


steel. Furthermore, differences can be observed regarding the running-in behavior comparing the two curve progressions at $0 \mathrm{~m} \leq s \leq 400 \mathrm{~m}$. A reason for this is the possibility of the in situ formation of a tribofilm composed of $\mathrm{MoS}_{2}$ and molybdenum oxides in the wear track. It was assumed, that already in the running-in stage at $s \leq 400 \mathrm{~m}$, the toplayer of the graded $(\mathrm{Cr}, \mathrm{Al}) \mathrm{N}+\mathrm{Mo}: \mathrm{S}$ coating provides sufficient $\mathrm{Mo}: \mathrm{S}$ for the in situ formation of $\mathrm{MoS}_{2}$. In addition, the formation of different molybdenum oxide $\mathrm{Mo}_{\mathrm{x}} \mathrm{O}_{\mathrm{y}}$ can not be excluded for fluid-free friction regime conditions at humid air.

In the first $s=400 \mathrm{~m}$ changes in the course of the curve of graded $(\mathrm{Cr}, \mathrm{Al}) \mathrm{N}+\mathrm{Mo}: \mathrm{S} / 100 \mathrm{Cr} 6$ can be observed. At first $\mu$ increases from the beginning to approximately $s \approx 175 \mathrm{~m}$. Afterwards the course of the curve is decreasing until $s \approx 275 \mathrm{~m}$ and subsequently increasing again. In order to analyze the supply and transfer mechanism of the graded $(\mathrm{Cr}, \mathrm{Al}) \mathrm{N}+\mathrm{Mo}: \mathrm{S}$ coating during this running-in stage, two distances $s=200 \mathrm{~m}$ and $s=400 \mathrm{~m}$ were chosen for deeper analysis of the supply und transfer mechanism in the running-in stage. The tribological analysis were conducted for $p_{\mathrm{H}}=\{400 ; 600 ; 800 ; 1300\} \mathrm{MPa}$ considering the influence of different Hertzian pressures on the supply mechanism of graded $(\mathrm{Cr}, \mathrm{Al}) \mathrm{N}+\mathrm{Mo}: \mathrm{S}$ coating and the related tribofilm formation.

\subsection{Chemical Analysis by Means of the Electron Probe Micro Analysis (EPMA)}

The chemical composition of the graded $(\mathrm{Cr}, \mathrm{Al}) \mathrm{N}+\mathrm{Mo}: \mathrm{S}$ coating by means of EPMA is a decisive analysis for correlation with the formed tribofilm and the related tribological investigations. To enable a determination of the chemical composition in dependence of the coating depth, EPMA analysis was conducted on a calotte at the Central Facility for Electron Microscopy (GfE), RWTH Aachen University, Aachen, Germany. The results are summed up in Table 4. The chemical compositions are based on a linear calculation due to the semicircle contour in profile of the calotte.

The subdivision into the four position at Table 4 can be followed based on the cross sectional micrographs of graded $(\mathrm{Cr}, \mathrm{Al}) \mathrm{N}+\mathrm{Mo}: \mathrm{S}$, Fig. 6. Herein also the fine crystalline structure of the interlayer and the intermediate layer can be observed. The toplayer shows an amorphous structure.

Starting from the interlayer, a thin metallic $\mathrm{Cr}$ and $\mathrm{Al}$ rich matrix of the graded $(\mathrm{Cr}, \mathrm{Al}) \mathrm{N}+\mathrm{Mo}: \mathrm{S}$ coating can be observed. An increase of the nitrogen share from $x_{\mathrm{N} 2}=4.3$ at $\%$ to $\mathrm{x}_{\mathrm{N} 2}=48.8$ at $\%$ causes a transition of the metallic $(\mathrm{Cr}, \mathrm{Al})$ matrix to a nitric $(\mathrm{Cr}, \mathrm{Al}) \mathrm{N}$ matrix with $x_{\mathrm{Al}}=6.2$ at $\%$ and $x_{\mathrm{Cr}}=16.6$ at $\%$. At the same time the shares of Mo and $\mathrm{S}$ are increased from $x_{\mathrm{Mo}}=x_{\mathrm{S}}=0$ at $\%$ at the
Table 4 Chemical composition of graded $(\mathrm{Cr}, \mathrm{Al}) \mathrm{N}+\mathrm{Mo}: \mathrm{S}$ from toplayer to interlayer

\begin{tabular}{llllcccc}
\hline Pos & Section & $\begin{array}{l}\text { Depth } \\
\text { S in } \mu \mathrm{m}\end{array}$ & $\begin{array}{l}\text { Cr } \\
\text { in at\% }\end{array}$ & $\begin{array}{l}\text { Al } \\
\text { in at\% }\end{array}$ & $\begin{array}{l}\text { N } \\
\text { in at\% }\end{array}$ & $\begin{array}{l}\text { Mo } \\
\text { in at\% }\end{array}$ & $\begin{array}{l}\text { S } \\
\text { in at\% }\end{array}$ \\
\hline 1 & Surface & 0.1 & 5.0 & 1.1 & 36.0 & 27.6 & 30.3 \\
2 & Toplayer & 1.0 & 1.2 & 0.3 & 26.4 & 33.7 & 38.4 \\
3 & Intermediate layer & 2.1 & 16.6 & 6.2 & 48.8 & 15.5 & 12.9 \\
4 & Interlayer & 3.0 & 84.8 & 10.5 & 4.3 & 0.3 & 0.1 \\
\hline
\end{tabular}

Fig. 6 Cross sectional micrograph of graded $(\mathrm{Cr}, \mathrm{Al})$ $\mathrm{N}+\mathrm{Mo}: \mathrm{S}[21]$
Graded $(\mathrm{Cr}, \mathrm{Al}) \mathrm{N}+\mathrm{Mo}: \mathrm{S}$

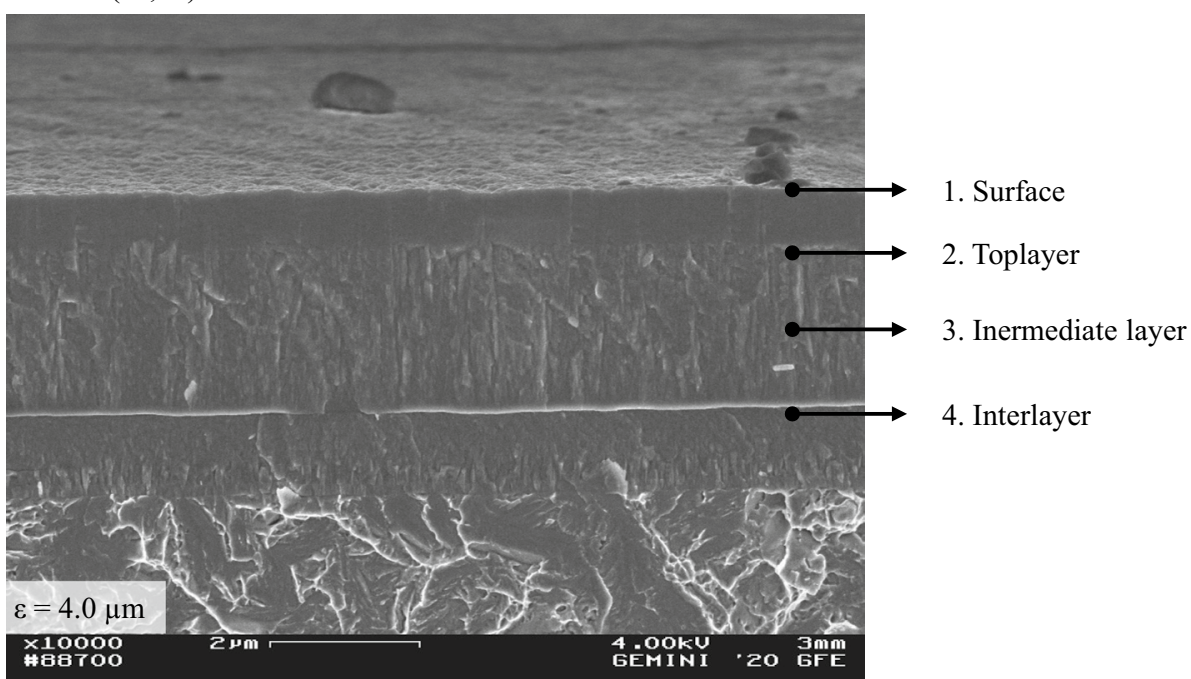


interlayer to $x_{\mathrm{Mo}}=15.5$ at $\%$ and $x_{\mathrm{S}}=12.9$ at $\%$ at the intermediate layer. Through this an embedding of the triboactive elements $\mathrm{Mo}$ and $\mathrm{S}$ in the $(\mathrm{Cr}, \mathrm{Al}) \mathrm{N}$ matrix is possible by simultaneously enabling a bonding to the interlayer. By reaching the toplayer at $\delta=1.0 \mu \mathrm{m}$ the shares of $x_{\mathrm{Mo}}=33.7$ at $\%$ and $x_{\mathrm{S}}=38.4$ at $\%$ are further increased in favor of the reduced shares of $x_{\mathrm{Cr}}=1.2$ at $\%, x_{\mathrm{Al}}=0.3$ at $\%$ and $x_{\mathrm{N} 2}=26.4$ at $\%$. Due to the changes of the nitrogen gas flow during the toplayer deposition the share of $x_{\mathrm{N} 2}=26.4$ at $\%$ is increased as well. The idea was to strengthen the coating matrix. The addition of the HPPMS cathodes leads to an increase of the shares of $x_{\mathrm{Cr}}=5.0$ at $\%, \mathrm{x}_{\mathrm{Al}}=1.1$ at $\%$ at the surface at $\delta=0.1 \mu \mathrm{m}$. Therefore, the shares of $x_{\mathrm{Mo}}=27.6$ at $\%$ and $x_{\mathrm{S}}=30.3$ at $\%$ are reduced in accordance with the rise of $\mathrm{Cr}, \mathrm{Al}$ and $\mathrm{N}_{2}$ shares. The high Mo and $\mathrm{S}$ content at the toplayer of the graded $(\mathrm{Cr}, \mathrm{Al}) \mathrm{N}+\mathrm{Mo}$ :S coating enables the formation of a Mo, S and $\mathrm{O}$ containing tribofilm under fluid-free friction regime at humid air and $T=20^{\circ} \mathrm{C}$.

\subsection{Analysis of the Wear Volume}

For the activation of the triboactive elements Mo and $\mathrm{S}$ out of the toplayer of the graded $(\mathrm{Cr}, \mathrm{Al}) \mathrm{N}+\mathrm{Mo}: \mathrm{S}$ coating initial wear is required, to enable the expected in situ formation of $\mathrm{MoS}_{2}$ and $\mathrm{Mo}_{\mathrm{x}} \mathrm{O}_{\mathrm{y}}$. Figure 7 shows the wear volumes of the basic parts for different distances $s$ and Hertzian pressures $\mathrm{p}_{\mathrm{H}}$ analyzed by means of CLSM. The wear volume at $p_{\mathrm{H}}=1300 \mathrm{MPas}=$ shows a higher value compared to the remaining wear volumes. This can be explained by a partial detachment of the coating. In the following, this value will not be considered further. The differences between the wear volumes of the remaining samples show only a low dependency on the Hertzian pressure and the two distances $s=200 \mathrm{~m}$ and $s=400 \mathrm{~m}$. The majority of this is believed to be running-in wear, which serves to activate the solid lubricant-forming elements supplied from the graded $(\mathrm{Cr}, \mathrm{Al})$ $\mathrm{N}+$ Mo:S coating.

In Fig. 8 the wear volumes of the uncoated counter parts at different distances and Hertzian pressures are shown. At

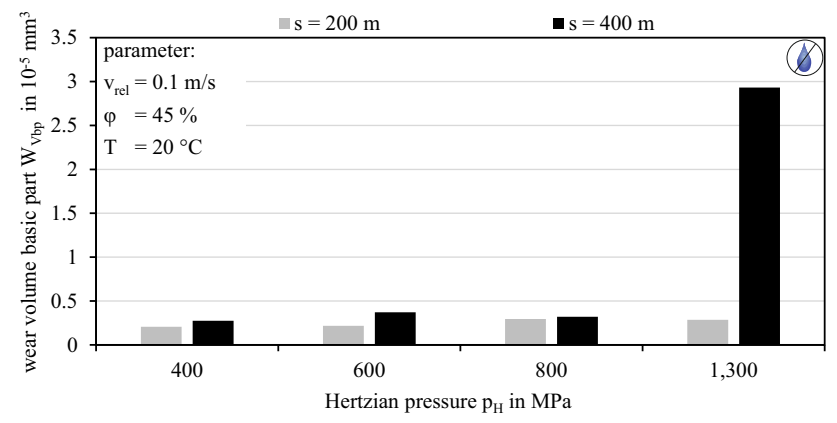

Fig. 7 Wear volume of $(\mathrm{Cr}, \mathrm{Al}) \mathrm{N}+\mathrm{Mo}: \mathrm{S}$ coated basic parts after tribological analysis

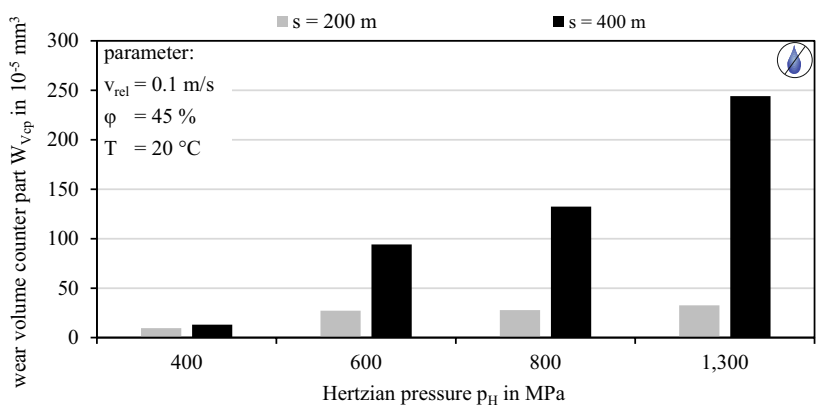

Fig. 8 Wear volume of uncoated $100 \mathrm{Cr} 6$ counter parts after tribological analysis

$p_{\mathrm{H}}=400 \mathrm{MPa}$ the differences between the wear volumes of the counter parts $s=200 \mathrm{~m}$ and $s=400 \mathrm{~m}$ are very small. This leads to the assumption that the counter parts are predominantly in contact with the tribofilm, which is composed with the shear soft $\mathrm{MoS}_{2}$ and, to an unknown share, $\mathrm{Mo}_{x} \mathrm{O}_{y}$. This leads to a consumption of the toplayer of the graded $(\mathrm{Cr}, \mathrm{Al}) \mathrm{N}+\mathrm{Mo}$ :S coating in the initial tribological process. After sinking into the toplayer, the counter part gets more and more in contact with the Mo and $\mathrm{S}$ modified $(\mathrm{Cr}, \mathrm{Al}) \mathrm{N}$ matrix due to the graded structure of the $(\mathrm{Cr}, \mathrm{Al}) \mathrm{N}+\mathrm{Mo}: \mathrm{S}$ coating. The wear volumes of the counter parts increase with higher Hertzian pressure and show a non-linear increase with longer running distances. The wear volume of the counter part at $p_{\mathrm{H}}=1300 \mathrm{MPa}$ shows a divergent behavior in this case.

It can be assumed, that the running-in process finished after the distance of $s=200 \mathrm{~m}$. Therefore, $s=200 \mathrm{~m}$ was chosen for further analysis. In order to gain a deeper understanding of the supply and transfer mechanisms of the tribofilm build out of the graded $(\mathrm{Cr}, \mathrm{Al}) \mathrm{N}+\mathrm{Mo}: \mathrm{S}$ coating, chemical analysis of the tribofilm at basic parts and counter parts were conducted.

\subsection{Raman Analysis of the Tribofilm on Wear Tracks at $p_{\mathrm{H}}=400 \mathrm{MPa}$ and $p_{\mathrm{H}}=1300 \mathrm{MPa}$}

Figure 9 shows a topography image of the wear track, the measurement positions as well as the recorded Raman spectra. In addition, a reference spectrum of the as-deposited $(\mathrm{Cr}, \mathrm{Al}) \mathrm{N}+\mathrm{Mo}: \mathrm{S}$ coating is shown for comparison. The peak at $\tilde{v}=296 \mathrm{~cm}^{-1}$ at the reference spectrum was assigned to $(\mathrm{Cr}, \mathrm{Al}) \mathrm{N}$ or MoN. Further peaks at $\tilde{v}=421 \mathrm{~cm}^{-1}$, $\tilde{v}=786 \mathrm{~cm}^{-1}$ and $\tilde{v}=939 \mathrm{~cm}^{-1}$ are based on $\mathrm{MoS}_{2}, \mathrm{MoN}$ and $\mathrm{Mo}_{\mathrm{x}} \mathrm{O}_{\mathrm{y}}$. Thereby, an oxidation of either elemental molybdenum or $\mathrm{MoS}_{2}$ can not be excluded although the laser power was low and a burning of the sample was not visible. A transformation of MoN to $\mathrm{Mo}_{x} \mathrm{O}_{y}$ is not believed, due to the strong covalent binding structure. Moreover, it can be observed that the wear marks $\mathrm{a}, \mathrm{b}$ and $\mathrm{d}$ contain a higher 
Fig. 9 Topography of the wear track at $(\mathrm{Cr}, \mathrm{Al}) \mathrm{N}+\mathrm{Mo}: \mathrm{S}$ coated basic part and Raman spectra at different positions after $p_{\mathrm{H}}=400 \mathrm{MPa}$ and $s=200 \mathrm{~m}$

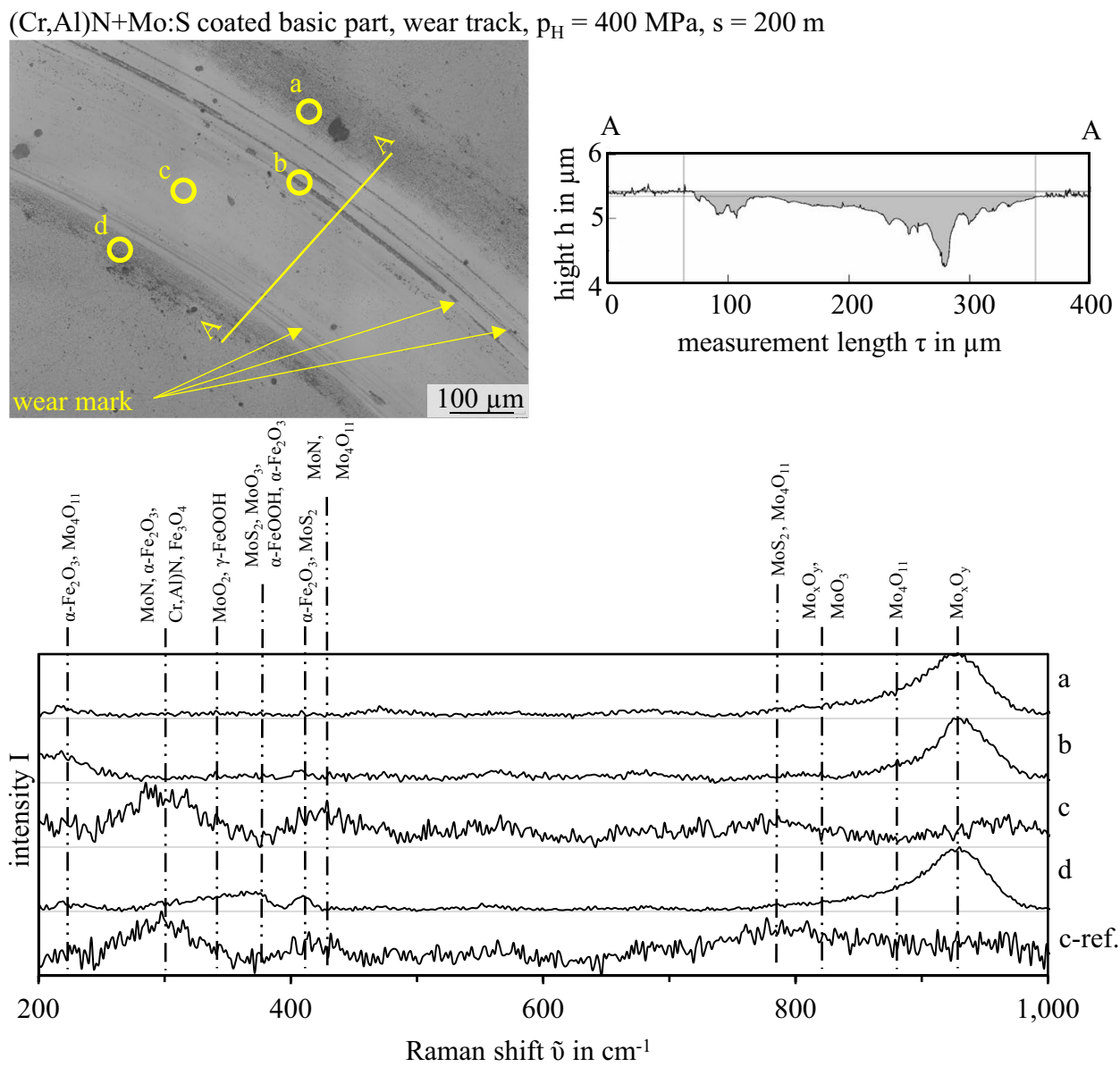

amount of molybdenum based bindings compared to the light grey marks at $\mathrm{c}$, Table 5. In addition, different iron oxides could be identified, which is a result of worn particles of the $100 \mathrm{Cr} 6$ counter part.

At the positions a and $d$ the built tribofilm was pressed towards the outer edge zone leading to an accumulation as a consequence of the tribological contact conditions in the PoD tribometer. The remaining tribofilm is transferred to the
100Cr6 counter part as it can be seen in Fig. 10. In Table 6 the identified peaks and related bindings on the counter part after testing at $p_{\mathrm{H}}=400 \mathrm{MPa}$ and $s=200 \mathrm{~m}$ are presented.

The counter part shows the analog dark grey marks like in the wear track on the basic part. Based on the topography analysis shown in Figs. 9 and 10 abrasion is the dominating wear mechanism, which can be identified on the wear marks at basic part and counter part. Adhesive wear cannot
Table 5 Identified peaks on wear track on $(\mathrm{Cr}, \mathrm{Al}) \mathrm{N}+\mathrm{Mo}: \mathrm{S}$ basic part after tribological testing against uncoated $100 \mathrm{Cr} 6$

\begin{tabular}{|c|c|c|c|c|c|c|c|}
\hline \multirow[t]{2}{*}{ Binding } & \multirow[t]{2}{*}{ Literature } & \multicolumn{5}{|c|}{$\begin{array}{l}(\mathrm{Cr}, \mathrm{Al}) \mathrm{N}+\mathrm{Mo}: \mathrm{S} \text { basic part, } \\
p_{\mathrm{H}}=400 \mathrm{MPa}, s=200 \mathrm{~m}\end{array}$} & \multirow[t]{2}{*}{ Source } \\
\hline & & $\bar{a}$ & $b$ & $c$ & $d$ & $\overline{c-r e f}$ & \\
\hline$\alpha-\mathrm{Fe}_{2} \mathrm{O}_{3}, \mathrm{Mo}_{4} \mathrm{O}_{11}$ & 226,229 & & 218 & & 220 & & {$[30,31]$} \\
\hline $\mathrm{MoN}, \alpha-\mathrm{Fe}_{2} \mathrm{O}_{3},(\mathrm{Cr}, \mathrm{Al}) \mathrm{N} \mathrm{Fe}_{3} \mathrm{O}_{4}$ & $285,293,296,298$ & & & 288 & 293 & 296 & [31-33] \\
\hline $\mathrm{MoO}_{2}, \mathrm{MoO}_{2}, \gamma-\mathrm{FeOOH}$ & $340,347,348$ & & & & 342 & & {$[30,34]$} \\
\hline $\mathrm{MoS}_{2}, \mathrm{MoO}_{3}, \alpha-\mathrm{FeOOH} \alpha-\mathrm{Fe}_{2} \mathrm{O}_{3}$ & $375,380,385,390$ & & & 381 & 372 & & {$[30,31,34,35]$} \\
\hline$\alpha-\mathrm{Fe}_{2} \mathrm{O}_{3}, \mathrm{MoS}_{2}$ & 400,408 & & & & 410 & & {$[35,36]$} \\
\hline $\mathrm{Mo}_{4} \mathrm{O}_{11}, \mathrm{MoN}$ & 431,432 & & & 426 & & 421 & {$[30,33]$} \\
\hline $\mathrm{MoS}_{2}, \mathrm{Mo}_{4} \mathrm{O}_{11}$ & 780,790 & & & & & 786 & {$[30,35]$} \\
\hline $\mathrm{Mo}_{x} \mathrm{O}_{y}, \mathrm{MoO}_{3}$ & 818,820 & 815 & 819 & & 813 & & {$[35,37]$} \\
\hline $\mathrm{Mo}_{4} \mathrm{O}_{11}$ & -880 & 873 & 884 & & 889 & & {$[30]$} \\
\hline $\mathrm{Mo}_{x} \mathrm{O}_{y}$ & 929 & 932 & 930 & & 931 & 939 & {$[35]$} \\
\hline
\end{tabular}


Fig. 10 Topography of the wear track at uncoated $100 \mathrm{Cr} 6$ counter part and Raman spectra at different positions after $p_{\mathrm{H}}=400 \mathrm{MPa}$ and $s=200 \mathrm{~m}$

\begin{tabular}{|c|c|c|c|c|c|c|c|}
\hline \multirow[t]{2}{*}{ Binding } & \multirow[t]{2}{*}{ Literature } & \multicolumn{5}{|c|}{$\begin{array}{l}100 \mathrm{Cr} 6 \text { counter part, } \\
p_{\mathrm{H}}=400 \mathrm{MPa}, s=200 \mathrm{~m}\end{array}$} & \multirow[t]{2}{*}{ Source } \\
\hline & & 1 & 2 & 3 & 4 & s-ref & \\
\hline $\mathrm{MoN} \mathrm{Mo}_{x} \mathrm{O}_{y}$ & 193,198 & 196 & & & & & {$[33,37]$} \\
\hline$\alpha-\mathrm{Fe}_{2} \mathrm{O}_{3}, \mathrm{Mo}_{4} \mathrm{O}_{11}$ & 226,229 & 219 & 226 & & & & {$[30,31]$} \\
\hline $\mathrm{Mo}_{4} \mathrm{O}_{11}$ & 264 & & 242 & & & & {$[30]$} \\
\hline $\mathrm{MoN}, \alpha-\mathrm{Fe}_{2} \mathrm{O}_{3}, \mathrm{Fe}_{3} \mathrm{O}_{4}$ & $285,293,298$ & & 295 & & & & {$[31,33]$} \\
\hline $\mathrm{Mo}_{4} \mathrm{O}_{11}$ & 306 & 309 & & & 310 & & {$[30]$} \\
\hline $\mathrm{MoO}_{2}, \mathrm{MoO}_{2}, \gamma-\mathrm{FeOOH}$ & $340,347,348$ & 335 & 336 & 332 & 345 & & {$[30,34]$} \\
\hline $\mathrm{MoS}_{2}, \mathrm{MoO}_{3}, \alpha-\mathrm{FeOOH} \alpha-\mathrm{Fe}_{2} \mathrm{O}_{3}$ & $375,380,385,390$ & 371 & 366 & 371 & 369 & & {$[30,31,34,35]$} \\
\hline$\alpha-\mathrm{Fe}_{2} \mathrm{O}_{3}, \mathrm{MoS}_{2}$ & 400,408 & 405 & 409 & 413 & 413 & & {$[35,36]$} \\
\hline $\mathrm{Mo}_{4} \mathrm{O}_{11}, \mathrm{MoN}$ & 431,432 & 433 & 435 & & 437 & & {$[30,33]$} \\
\hline $\mathrm{MoS}_{2}, \mathrm{Mo}_{4} \mathrm{O}_{11}, \mathrm{MoO}_{2}$ & $450,452,458$ & & 446 & & & & {$[30,39]$} \\
\hline $\mathrm{MoO}_{2}$ & 461 & & & 470 & & & {$[30]$} \\
\hline $\mathrm{MoN}, \mathrm{MoS}_{2}, \gamma-\mathrm{FeOOH}$ & 522,528 & & 523 & & & & [33-35] \\
\hline $\mathrm{MoN}, \mathrm{Fe}_{3} \mathrm{O}_{4}, \mathrm{Cr}_{2} \mathrm{O}_{3}, \mathrm{Mo}_{4} \mathrm{O}_{11}$ & $541 ; 569,560,565,568$ & 559 & 554 & & 549 & 586 & {$[30,33,35,40]$} \\
\hline$\alpha-\mathrm{Fe}_{2} \mathrm{O}_{3} \mathrm{Fe}_{3} \mathrm{O}_{4}$ & 660,661 & & & & & 677 & {$[31,41]$} \\
\hline $\mathrm{Cr}_{\mathrm{e}} \mathrm{O}_{\mathrm{d}}$ & -810 & & & & & 797 & {$[42]$} \\
\hline $\mathrm{Mo}_{4} \mathrm{O}_{11}, \mathrm{MoO}_{3}, \mathrm{Mo}_{x} \mathrm{O}_{y}$ & 840,843 & 838 & 832 & & 835 & & {$[30,35]$} \\
\hline $\mathrm{Mo}_{4} \mathrm{O}_{11}$ & -880 & 877 & 891 & & 889 & & {$[30]$} \\
\hline $\mathrm{Mo}_{x} \mathrm{O}_{y}$ & 929 & 928 & 934 & & 931 & & {$[35]$} \\
\hline
\end{tabular}
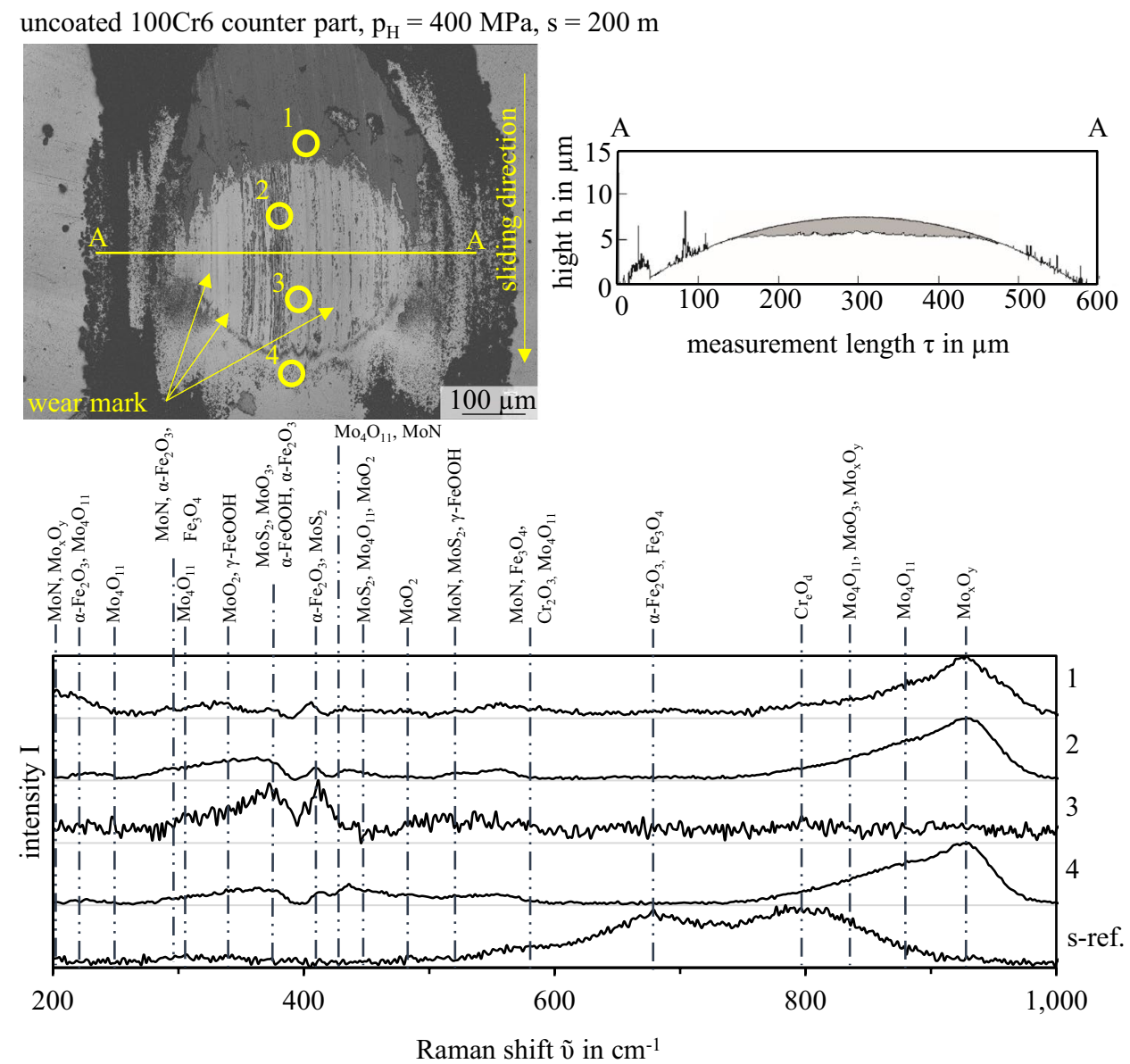

Raman shift $\tilde{v}$ in $\mathrm{cm}^{-1}$
Table 6 Identified peaks on 100Cr6 uncoated ball after tribological testing against graded $(\mathrm{Cr}, \mathrm{Al}) \mathrm{N}+\mathrm{Mo}: \mathrm{S}$ 
be observed, although it is one of the decisive wear mechanisms in steel/steel contacts under fluid-free friction regime [38]. Due to the self-lubricating toplayer and the related tribofilm formation the frictional heat generation between the two contacting surfaces is reduced and the occurrence of adhesion can be avoided.

The Raman spectrum of the $100 \mathrm{Cr} 6$ reference proves the chemical composition at the surface of $\mathrm{Cr}_{2} \mathrm{O}_{3}$ at $\tilde{v}=586 \mathrm{~cm}^{-1}$ and $\mathrm{Cr}_{\mathrm{e}} \mathrm{O}_{\mathrm{d}} \tilde{v}=797 \mathrm{~cm}^{-1}$ as well as $\mathrm{Fe}_{3} \mathrm{O}_{4}$ at $\tilde{v}=586 \mathrm{~cm}^{-1}$ and $\alpha-\mathrm{Fe}_{2} \mathrm{O}_{3}$ or $\mathrm{Fe}_{3} \mathrm{O}_{4}$ at $\tilde{v}=677 \mathrm{~cm}^{-1}$. Furthermore, an increased dark section in front of the contact area of the uncoated $100 \mathrm{Cr} 6$ ball at position $1 \mathrm{can}$ be observed. The Raman spectrum of position 1 proves the formation of the tribofilm composed of $\mathrm{MoS}_{2}$ and different $\mathrm{Mo}_{\mathrm{x}} \mathrm{O}_{\mathrm{y}}$ bindings out of the triboactive coating and worn iron oxide $\mathrm{Fe}_{\mathrm{a}} \mathrm{O}_{\mathrm{b}}$ particles of the $100 \mathrm{Cr} 6$ counter part. The share of MoN in the tribofilm appears to be very low, so that the effect on the tribological behavior only takes place on a subordinate function. Position 1 can be described as a tribofilm accumulation which continuously supplies the sliding surfaces with $\mathrm{MoS}_{2}$ and $\mathrm{Mo}_{\mathrm{x}} \mathrm{O}_{\mathrm{y}}$ as well as the solid lubricant-forming elements Mo and $\mathrm{S}$ from the $(\mathrm{Cr}, \mathrm{Al}) \mathrm{N}+\mathrm{Mo}$ :S coating.

The Raman measurement shown in Figs. 9 and 10 prove the early formation of a self-lubricating tribofilm in the tribological contact after $p_{\mathrm{H}}=400 \mathrm{MPa}$ and $s=200 \mathrm{~m}$ composed of molybdenum oxides and $\mathrm{MoS}_{2}$. The overview in Table 5 and Table 6 reveals, that the amount of molybdenum oxides is increased compared to the amount of $\mathrm{MoS}_{2}$. This leads to the conclusion, that in the examined fluid-free friction regime, the observed friction and wear reduction is dominated by $\mathrm{Mo}_{x} \mathrm{O}_{y}$ compared to $\mathrm{MoS}_{2}$.

Figure 11 shows the topographical and chemical analysis of the wear track on $(\mathrm{Cr}, \mathrm{Al}) \mathrm{N}+\mathrm{Mo}: \mathrm{S}$ after testing at $p_{\mathrm{H}}=1300 \mathrm{MPa}$ and $s=200 \mathrm{~m}$. The wear marks on the basic part show a more defined contour and the dark grey marks are more pronounced compared to the wear marks at $p_{\mathrm{H}}=400 \mathrm{MPa}$.

However, the chemical composition of the tribofilm from $p_{\mathrm{H}}=400 \mathrm{MPa}$ to $p_{\mathrm{H}}=1300 \mathrm{MPa}$ does not change significantly by comparing Tables 5 and 7 . With regard to the position $a$ and $b$ at Figs. 9 and 11 it can be observed, that the bindings in the area of $280 \mathrm{~cm}^{-1} \leq \tilde{v} \leq 450 \mathrm{~cm}^{-1}$ are build faster at $p_{\mathrm{H}}=1300 \mathrm{MPa}$ due to the higher tribological load impact compared to $p_{\mathrm{H}}=400 \mathrm{MPa}$. Nevertheless, the Hertzian pressure has no significant influence on the chemical composition of the tribofilm out of the triboactive $(\mathrm{Cr}, \mathrm{Al})$ $\mathrm{N}+\mathrm{Mo}: \mathrm{S}$ coating in fluid-free friction regime. Figure 12 shows the topography of the wear tracks on the uncoated
Fig. 11 Topography of the wear track at $(\mathrm{Cr}, \mathrm{Al}) \mathrm{N}+\mathrm{Mo}: \mathrm{S}$ coated basic part and Raman spectra at different positions after $p_{\mathrm{H}}=1300 \mathrm{MPa}$ and $s=200 \mathrm{~m}$

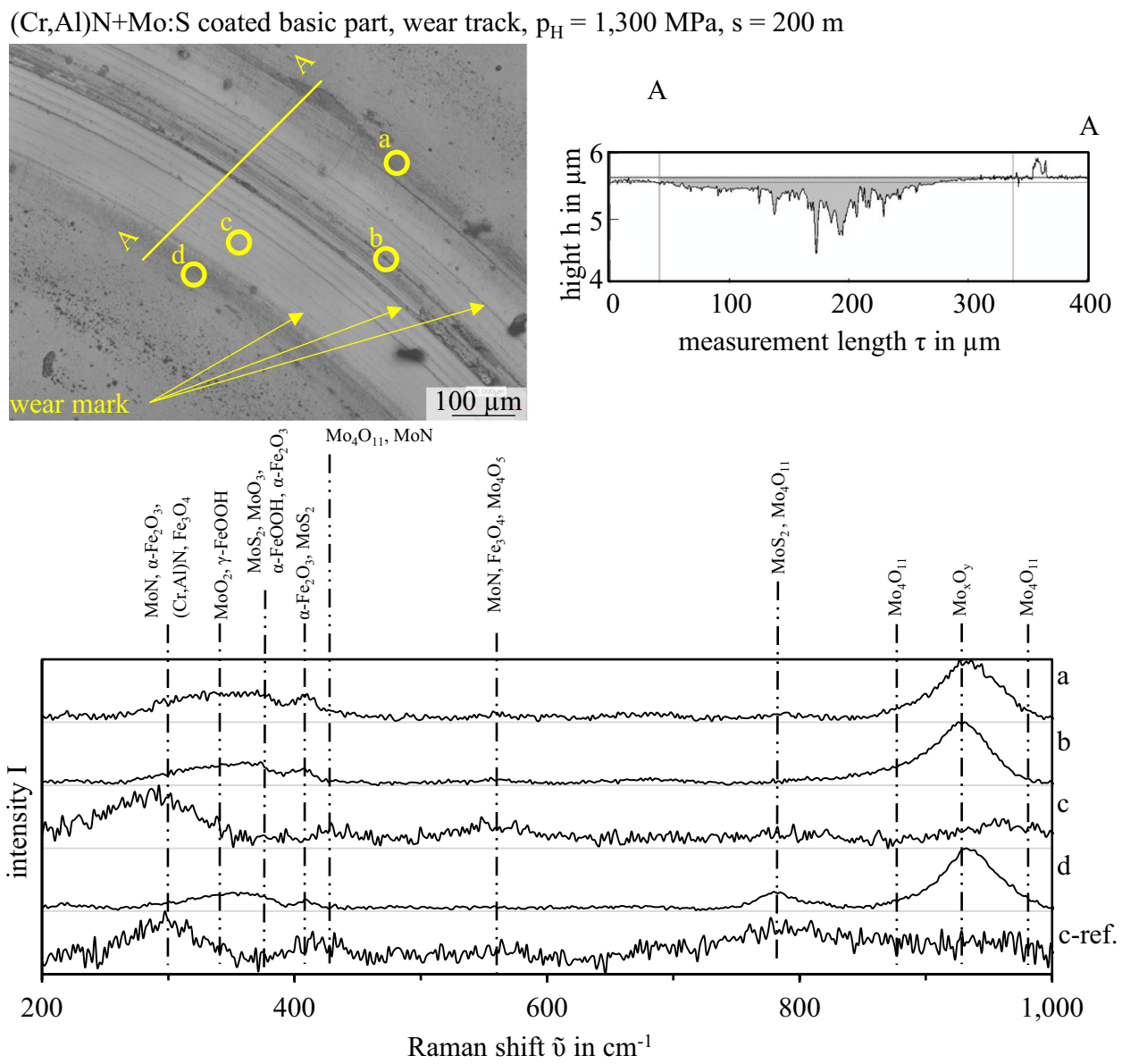


Table 7 Identified peaks on wear track on $(\mathrm{Cr}, \mathrm{Al}) \mathrm{N}+\mathrm{Mo}: \mathrm{S}$ basic part after tribological testing against uncoated $100 \mathrm{Cr} 6$

\begin{tabular}{|c|c|c|c|c|c|c|c|}
\hline \multirow[t]{2}{*}{ Binding } & \multirow[t]{2}{*}{ Literature } & \multicolumn{5}{|c|}{$\begin{array}{l}(\mathrm{Cr}, \mathrm{Al}) \mathrm{N}+\mathrm{Mo}: \mathrm{S} \text { basic part, } \\
p_{\mathrm{H}}=1300 \mathrm{MPa}, s=200 \mathrm{~m}\end{array}$} & \multirow[t]{2}{*}{ Source } \\
\hline & & $a$ & $b$ & $c$ & $d$ & c-ref & \\
\hline $\mathrm{MoN} \alpha-\mathrm{Fe}_{2} \mathrm{O}_{3},(\mathrm{Cr}, \mathrm{Al}) \mathrm{N} \mathrm{Fe}_{3} \mathrm{O}_{4}$ & $285,293,296,298$ & & & 285 & & 296 & [31-33] \\
\hline $\mathrm{Fe}_{3} \mathrm{O}_{4}$ & 320 & 322 & & & & & [31] \\
\hline $\mathrm{MoO}_{2}, \mathrm{MoO}_{2}, \gamma-\mathrm{FeOOH}$ & $340,347,348$ & & 330 & & 341 & & {$[30,34]$} \\
\hline $\mathrm{MoS}_{2}, \mathrm{MoO}_{3}, \alpha-\mathrm{FeOOH} \alpha-\mathrm{Fe}_{2} \mathrm{O}_{3}$ & $375,380,385,390$ & 369 & 368 & & 368 & & {$[30,31,34,35]$} \\
\hline$\alpha-\mathrm{Fe}_{2} \mathrm{O}_{3}, \mathrm{MoS}_{2}$ & 400,408 & 409 & 406 & & 410 & & {$[35,36]$} \\
\hline $\mathrm{Mo}_{4} \mathrm{O}_{11}, \mathrm{MoN}$ & 431,432 & 427 & & & & 421 & {$[30]$} \\
\hline $\mathrm{MoN}, \mathrm{Fe}_{3} \mathrm{O}_{4}, \mathrm{Mo}_{4} \mathrm{O}_{11}$ & $541 ; 569,560,568$ & & & 556 & & & {$[30,33,35]$} \\
\hline $\mathrm{MoS}_{2}, \mathrm{Mo}_{4} \mathrm{O}_{11}$ & 780,790 & & & & 782 & 786 & {$[30,35]$} \\
\hline $\mathrm{Mo}_{4} \mathrm{O}_{11}$ & -880 & 884 & 893 & & 884 & & {$[30]$} \\
\hline $\mathrm{Mo}_{x} \mathrm{O}_{y}$ & 929 & 934 & 931 & & 935 & 939 & {$[35]$} \\
\hline $\mathrm{Mo}_{4} \mathrm{O}_{11}$ & 985 & & 961 & & & & [30] \\
\hline
\end{tabular}

Fig. 12 Topography of the wear track at uncoated $100 \mathrm{Cr} 6$ counter part and Raman spectra at different positions after $p_{\mathrm{H}}=1300 \mathrm{MPa}$ and $s=200 \mathrm{~m}$

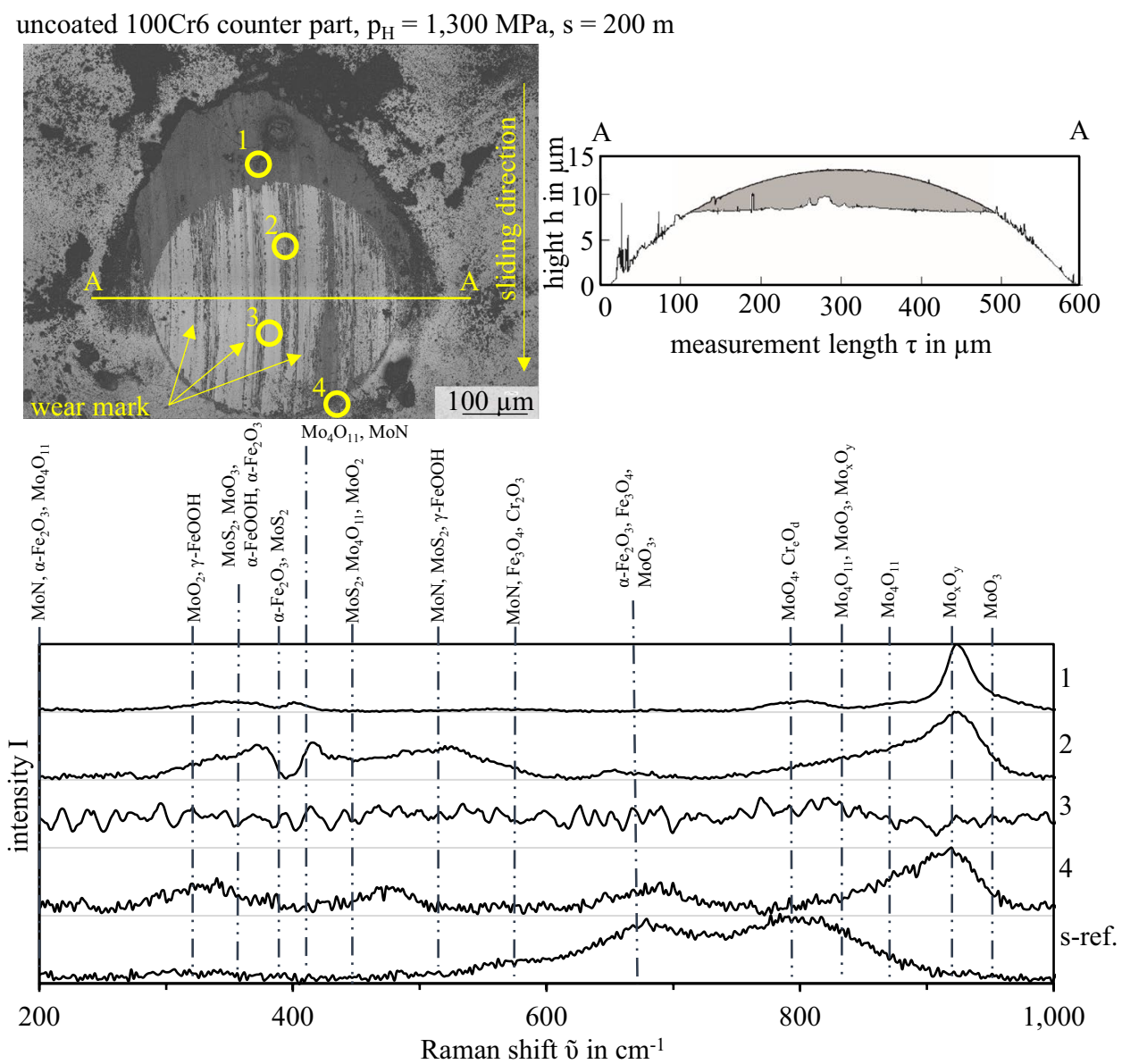

$100 \mathrm{Cr} 6$ counter part after testing at $p_{\mathrm{H}}=1300 \mathrm{MPa}$ and $s=200 \mathrm{~m}$ (Table 8).

Similar to the findings of the tribofilm accumulation in front of the sliding direction on the $100 \mathrm{Cr} 6$ counter part at $p_{\mathrm{H}}=400 \mathrm{MPa}$, the same accumulation can be observed in the topography image for $p_{\mathrm{H}}=1300 \mathrm{MPa}$. By taking the chemical composition of the graded $(\mathrm{Cr}, \mathrm{Al}) \mathrm{N}+\mathrm{Mo}: \mathrm{S}$ coating into account, the share of sulfur with $x_{\mathrm{S}}=38.4$ at $\%$ at the toplayer is insufficient to bond the molybdenum with $x_{\mathrm{Mo}}=33.7$ at. $\%$ stoichiometrically to $\mathrm{MoS}_{2}$.

Out of the nitrogen share of $x_{\mathrm{N} 2}=26.4$ at $\%$ at the toplayer the formation of $\mathrm{CrN}$ by the small share of chromium with $x_{\mathrm{Cr}}=1.2$ at $\%$ is possible. The remaining $\mathrm{N}$ 
Table 8 Identified peaks on 100Cr6 uncoated ball after tribological testing against graded $(\mathrm{Cr}, \mathrm{Al}) \mathrm{N}+\mathrm{Mo}: \mathrm{S}$

\begin{tabular}{|c|c|c|c|c|c|c|c|}
\hline \multirow[t]{2}{*}{ Binding } & \multirow[t]{2}{*}{ Literature } & \multicolumn{5}{|c|}{$\begin{array}{l}100 \mathrm{Cr} 6 \text { counter part, } \\
p_{\mathrm{H}}=1300 \mathrm{MPa}, s=200 \mathrm{~m}\end{array}$} & \multirow[t]{2}{*}{ Source } \\
\hline & & 1 & 2 & 3 & 4 & s-ref & \\
\hline $\mathrm{MoN}, \mathrm{Mo}_{\mathrm{x}} \mathrm{O}_{\mathrm{y}}$ & 193,198 & 193 & & & & & {$[33,37]$} \\
\hline$\alpha-\mathrm{Fe}_{2} \mathrm{O}_{3}, \mathrm{Mo}_{4} \mathrm{O}_{11}$ & 226,229 & 219 & & & & & {$[30,31]$} \\
\hline $\mathrm{MoO}_{2}, \gamma-\mathrm{FeOOH}$ & $340 ; 347,348$ & 348 & 342 & & 330 & & {$[30,34]$} \\
\hline $\mathrm{MoS}_{2}, \mathrm{MoO}_{3}, \alpha-\mathrm{FeOOH} \alpha-\mathrm{Fe}_{2} \mathrm{O}_{3}$ & $375,380,385,390$ & & 373 & & & & {$[30,31,34,35]$} \\
\hline$\alpha-\mathrm{Fe}_{2} \mathrm{O}_{3}, \mathrm{MoS}_{2}$ & 400,408 & 404 & 415 & & & & {$[35,36]$} \\
\hline $\mathrm{Mo}_{4} \mathrm{O}_{11}, \mathrm{MoN}$ & 431,432 & & 435 & & & & {$[30,33]$} \\
\hline $\mathrm{MoS}_{2}, \mathrm{MoO}_{3}$ & 466,469 & & 470 & & 474 & & {$[30,35]$} \\
\hline $\mathrm{MoN} \mathrm{MoS}_{2} \gamma-\mathrm{FeOOH}$ & 522,528 & & 523 & & & & {$[33,35]$} \\
\hline $\mathrm{MoN}, \mathrm{Fe}_{3} \mathrm{O}_{4}, \mathrm{Cr}_{2} \mathrm{O}_{3}$ & $541 ; 569,560,565$ & & & & & 586 & {$[33,40]$} \\
\hline$\alpha-\mathrm{Fe}_{2} \mathrm{O}_{3} \mathrm{Fe}_{3} \mathrm{O}_{4} \mathrm{MoO}_{3}$ & $660,661,667$ & & 657 & & 684 & 677 & {$[30,31,41]$} \\
\hline $\mathrm{MoO}_{4}, \mathrm{Cr}_{\mathrm{e}} \mathrm{O}_{\mathrm{d}}$ & $790, \sim 810$ & 800 & & & & 797 & {$[30,42]$} \\
\hline $\mathrm{Mo}_{4} \mathrm{O}_{11}, \mathrm{MoO}_{3}, \mathrm{Mo}_{x} \mathrm{O}_{y}$ & 840,843 & & 855 & & 859 & & {$[30,35]$} \\
\hline $\mathrm{Mo}_{4} \mathrm{O}_{11}$ & $\sim 880$ & 873 & 894 & & & & [30] \\
\hline $\mathrm{Mo}_{4} \mathrm{O}_{11}$ & 907 & & & & 914 & & [30] \\
\hline $\mathrm{Mo}_{x} \mathrm{O}_{y}$ & 929 & 925 & 927 & & & & [35] \\
\hline $\mathrm{MoO}_{3}$ & 952 & & & & & & [37] \\
\hline
\end{tabular}

seems to be bonded to Mo or could be interstitial present in the amorphous coating matrix.

However, proving of different molybdenum oxide bindings in the tribofilm leads to the hypothesis, that molybdenum is partially present in an unbonded metallic form in a sort of depot. This depot is opened by wear of the toplayer and enables the in situ formation of molybdenum oxide bindings. The idea is based on the assumption that, MoN bindings will not break due to the low heat input as a result of the friction reducing tribofilm in the considered tribological contact. Also elemental Sulfur (unbonded) could be present in a sort of depot, since the formation of $\mathrm{MoS}_{2}$ was not stoichiometrically proven by means of $\mathrm{x}$-ray diffraction (XRD) shown in [21]. In order to prove the possible depot character of Mo and $\mathrm{S}$ at the toplayer of the graded triboactive $(\mathrm{Cr}, \mathrm{Al}) \mathrm{N}+\mathrm{Mo}: \mathrm{S}$ coating, XPS analysis were conducted. Furthermore, the chemical compositions of the tribofilm at the basic part after $p_{\mathrm{H}}=1300 \mathrm{MPa}$ and on the $100 \mathrm{Cr} 6$ counter part at $p_{\mathrm{H}}=1300 \mathrm{MPa}$ were analyzed. The focus of the XPS analysis was set on the elements Mo, S and O, since these are primarily responsible for the tribological behavior of the tribofilm, in contrast to $\mathrm{Fe}$ and $\mathrm{N}$. The quantification of nitrogen could also not be proceeded due to a superposition of the photo lines of Mo and N.

\subsection{XPS Analysis of the Triboactive $(\mathrm{Cr}, \mathrm{Al}) \mathrm{N}+\mathrm{Mo:S}$ Coating and the Build Tribofilm on Wear Tracks at $p_{\mathrm{H}}=1300 \mathrm{MPa}$}

The in-depth XPS analysis were conducted at the three different stages named surface-before sputtering, $t=5 \mathrm{~min}$ sputtering time and $t=120 \mathrm{~min}$ sputtering time. It is believed, that after $t=5 \mathrm{~min}$ sputtering time the XPS spectra represent the chemical composition of the tribofilm and after $t=120 \mathrm{~min}$ sputtering time the chemical composition of the toplayer of the graded $(\mathrm{Cr}, \mathrm{Al}) \mathrm{N}+\mathrm{Mo}: \mathrm{S}$ coating under the wear track. Figure 13 shows the XPS analysis of the tribofilm on the wear track on the $(\mathrm{Cr}, \mathrm{Al}) \mathrm{N}+\mathrm{Mo}: \mathrm{S}$ coated basic part after $t=5 \mathrm{~min}$ sputtering time. The evaluation of the spectra was conducted on the main lines of Mo 3d, S 2p and $\mathrm{O} 1 \mathrm{~s}$, whereby a superposition of two or more elements could be excluded. Consequently, the superimposed S $2 \mathrm{~s}$ line in the Mo 3d spectra was not considered.

Here, molybdenum was found in different states according to the measured oxidation numbers of Mo. The analysis proves the formation of Mo(IV), which can be assigned to $\mathrm{MoS}_{2}$ as well as to $\mathrm{MoO}_{2}$. A direct distinction between $\mathrm{MoS}_{2}$ and $\mathrm{MoO}_{2}$ is not possible by exclusively considering the spectra of Mo. Notwithstanding, a differentiated statement is possible by comparing the bonding states of molybdenum and sulfur in Tables 9 and 10 in different penetration depths (Table 11).

It can be observed, that the share of Mo(IV) varies between 5.6 at $\% \leq \varphi \leq 7.4$ at $\%$ from the surface to the toplayer of the coating. Parallel thereto, the share of sulfide increases from $\varphi=4.3$ at $\%$ at the surface of the tribofilm to $\varphi=20$ at $\%$ inside the coating. Based on these findings and the presented results by means of Raman spectroscopy it can be assumed, that at the surface of the tribofilm the ratio of $\mathrm{Mo}(\mathrm{IV})$ is in favor of $\mathrm{MoO}_{2}$ towards $\mathrm{MoS}_{2}$ and turns into the opposite for the ratio at $t=120$ min sputtering time inside the toplayer of $(\mathrm{Cr}, \mathrm{Al}) \mathrm{N}+\mathrm{Mo}: \mathrm{S}$. This conclusion can also 
Fig. 13 XPS spectrum of Mo, $\mathrm{S}$ and $\mathrm{O}$ after $t=5$ min sputtering time of the tribofilm on the wear track on $(\mathrm{Cr}, \mathrm{Al})$ $\mathrm{N}+\mathrm{Mo}: \mathrm{S}$ coated basic part after $p_{\mathrm{H}}=1300 \mathrm{MPa}$ and $s=200 \mathrm{~m}$
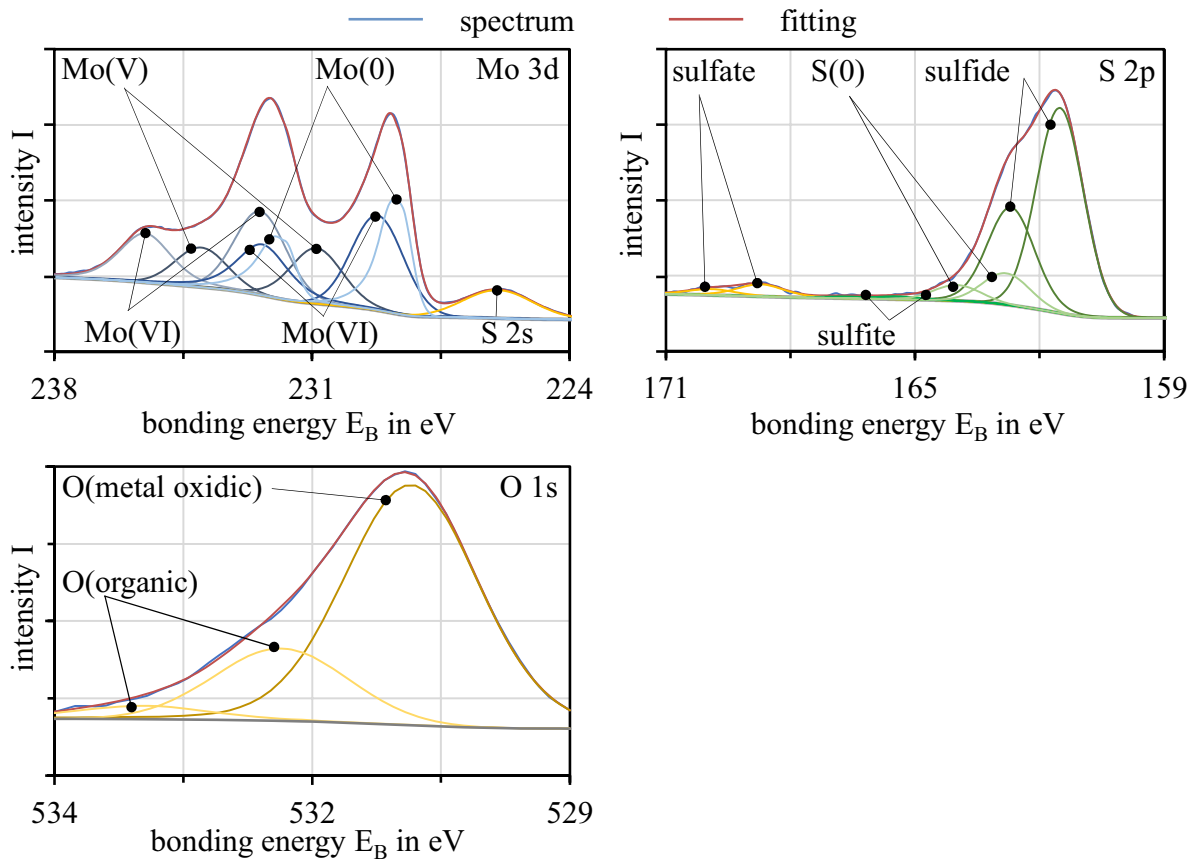

\begin{tabular}{|c|c|c|c|c|c|c|c|c|}
\hline \multirow[t]{2}{*}{ Information depth } & \multicolumn{2}{|c|}{ Mo (VI) } & \multicolumn{2}{|c|}{ Mo (V) } & \multicolumn{2}{|c|}{ Mo (IV) } & \multicolumn{2}{|l|}{ Mo (0) } \\
\hline & in at $\%$ & in $\%$ & in at $\%$ & in $\%$ & in at $\%$ & in $\%$ & in at $\%$ & in $\%$ \\
\hline Surface before sputtering & 9.7 & 54 & 2.2 & 12 & 6.1 & 34 & - & - \\
\hline$t=5$ min sputtering time & 6.5 & 27 & 4.6 & 19 & 7.4 & 31 & 5.5 & 23 \\
\hline$t=120 \mathrm{~min}$ sputtering time & 1.6 & 6 & 2.8 & 10 & 5.6 & 20 & 18 & 64 \\
\hline
\end{tabular}

Bold values represent the percentage of the corresponding oxidation state of the element

\begin{tabular}{|c|c|c|c|c|c|c|c|c|}
\hline \multirow[t]{2}{*}{ Information depth } & \multicolumn{2}{|c|}{ Sulfide } & \multicolumn{2}{|l|}{$S(0)$} & \multicolumn{2}{|l|}{ Sulfate } & \multicolumn{2}{|l|}{ Sulfite } \\
\hline & in at $\%$ & in $\%$ & in at $\%$ & in $\%$ & in at $\%$ & in $\%$ & in at $\%$ & in $\%$ \\
\hline Surface before sputtering & 4.3 & 67 & 1.0 & 15 & 1.0 & 16 & 0.1 & 2 \\
\hline$t=5$ min sputtering time & 15 & 81 & 2.3 & 13 & 0.9 & 5 & 0.2 & $\mathbf{1}$ \\
\hline$t=120 \mathrm{~min}$ sputtering time & 20 & 83 & 3.8 & 16 & - & - & 0.4 & 1 \\
\hline
\end{tabular}

Bold values represent the percentage of the corresponding oxidation state of the element
Table 10 XPS analysis of sulfur on the wear track on $(\mathrm{Cr}, \mathrm{Al})$ $\mathrm{N}+\mathrm{Mo}: \mathrm{S}$ after tribological testing at $p_{\mathrm{H}}=1300 \mathrm{MPa}$ and $s=200 \mathrm{~m}$ track on $(\mathrm{Cr}$ after tribological testing at $p_{\mathrm{H}}=1300 \mathrm{MPa}$ and $s=200 \mathrm{~m}$

Table 11 XPS analysis of $\mathrm{O}$ on the wear track on $(\mathrm{Cr}, \mathrm{Al}) \mathrm{N}+\mathrm{Mo}: \mathrm{S}$ after tribological testing at $p_{\mathrm{H}}=1300 \mathrm{MPa}$ and $s=200 \mathrm{~m}$

\begin{tabular}{llllll}
\hline Information depth & \multicolumn{2}{l}{ O (metal oxide) } & & \multicolumn{2}{l}{ O (organic) } \\
\cline { 2 - 3 } \cline { 6 - 7 } \cline { 6 - 7 } & in at $\%$ & in $\%$ & & in at $\%$ & in $\%$ \\
\hline Surface before sputtering & 16 & $\mathbf{5 3}$ & & 15 & $\mathbf{4 7}$ \\
$t=5$ min sputtering time & 25 & $\mathbf{7 8}$ & & 7.0 & $\mathbf{2 2}$ \\
$t=120$ min sputtering time & 13 & $\mathbf{7 5}$ & & 4.3 & $\mathbf{2 5}$ \\
\hline
\end{tabular}

Bold values represent the percentage of the corresponding oxidation state of the element be drawn based on the percentages of molybdenum oxides $\mathrm{Mo}(\mathrm{VI})$ and $\mathrm{Mo}(\mathrm{V})$ compared to the percentages of $\mathrm{Mo}(\mathrm{IV})$.

The detection of the metastable $\mathrm{Mo}(\mathrm{V})\left(\mathrm{Mo}_{2} \mathrm{O}_{5}\right)$ was interpreted as a reduction of $\mathrm{Mo}(\mathrm{VI})\left(\mathrm{MoO}_{3}\right)$ due to the impact of $\mathrm{X}$ rays during the measurement. This conclusion is analogous to the findings reported by Baltrusaitis et al. [43]. The in-depth analysis shows that the share of $\mathrm{MoO}_{3}$ dominates compared to Mo(IV) at the surfaces of the tribofilm and is reduced after $t=5 \mathrm{~min}$ and $t=120 \mathrm{~min}$ sputtering time, Table 9.

At the surface of the tribofilm molybdenum is not present in the elemental state (unbonded). After $t=5 \mathrm{~min}$ sputtering 
time the share of $\operatorname{Mo}(0)$ increases to $\varphi=5.5$ at $\%$, which is equivalent to $23 \%$ of the found molybdenum bonding states. Beneath the wear track in the toplayer of the graded $(\mathrm{Cr}, \mathrm{Al}) \mathrm{N}+\mathrm{Mo}: \mathrm{S}$ coating the share of unbonded molybdenum increases further to $\varphi=18$ at $\%$, which is a clear prove for the presence of unbonded molybdenum at the toplayer. It is also the highest percentage with $64 \%$ in comparison to $\mathrm{Mo}(\mathrm{VI}), \mathrm{Mo}(\mathrm{V})$ and $\mathrm{Mo}(\mathrm{IV})$. Furthermore, the share of elemental sulfur increases from the surface to the toplayer of the coating from $\varphi=1.0$ at $\%$ to $\varphi=3.8$ at $\%$. This leads to the conclusion, that the solid-lubricating forming elements Mo and $\mathrm{S}$ are present in unbonded states besides the presence of $\mathrm{MoS}_{2}$ at the toplayer. Besides molybdenum, sulfur also reacts with oxygen, leading to the formation of sulfates and sulfites with predominantly low shares.

\subsection{XPS Analysis of the Transferred Tribofilm on the Uncoated $100 \mathrm{Cr} 6$ Counter Part at $p_{\mathrm{H}}=1300 \mathrm{MPa}$}

The in-depth XPS analysis of the tribofilm on the uncoated $100 \mathrm{Cr} 6$ counter part were carried out likewise the above mentioned XPS analysis at three different stages. Here, the results after $t=5 \mathrm{~min}$ sputtering time can be interpreted as the chemical composition of the tribofilm. After $t=120 \mathrm{~min}$ sputtering time the spectra represent the chemical composition of the tribofilm and the surface of the $100 \mathrm{Cr} 6$ counter part. The measurements were conducted at position 1 shown in the topographical analysis by means of Raman spectroscopy, Fig. 12. The XPS spectra of Mo, S and O are shown in Fig. 14 and also prove the transfer of the tribofilm from the basic part to the counter part at $p_{\mathrm{H}}=1300 \mathrm{MPa}$ and $s=200 \mathrm{~m}$.

The quantitative results of Mo, S and $\mathrm{O}$ on the $100 \mathrm{Cr} 6$ counter part after $p_{\mathrm{H}}=1300 \mathrm{MPa}$ and $s=200 \mathrm{~m}$ are presented in Tables 12,13 and 14. Analog to the basic part, the shares of the molybdenum oxides $\mathrm{Mo}(\mathrm{VI})$ and $\mathrm{Mo}(\mathrm{V})$ are dominating inside the tribofilm with $86 \%$ in total in favor of $\mathrm{Mo}(\mathrm{IV})$ with $14 \%$, which has to be subdivided into $\mathrm{MoO}_{2}$ and $\mathrm{MoS}_{2}$.

An exception could be the chemical composition after $t=120$ min sputtering time, where the share of sulfide with $\varphi=1.9$ at $\%$ is equivalent to $74 \%$ of the bonded sulfur and Mo(IV) corresponds to $47 \%$ of molybdenum.
Fig. 14 XPS spectrum of Mo, S and $\mathrm{O}$ after $t=5$ min sputtering time of the tribofilm on the $100 \mathrm{Cr} 6$ counter part after testing at $p_{\mathrm{H}}=1300 \mathrm{MPa}$ and $s=200 \mathrm{~m}$
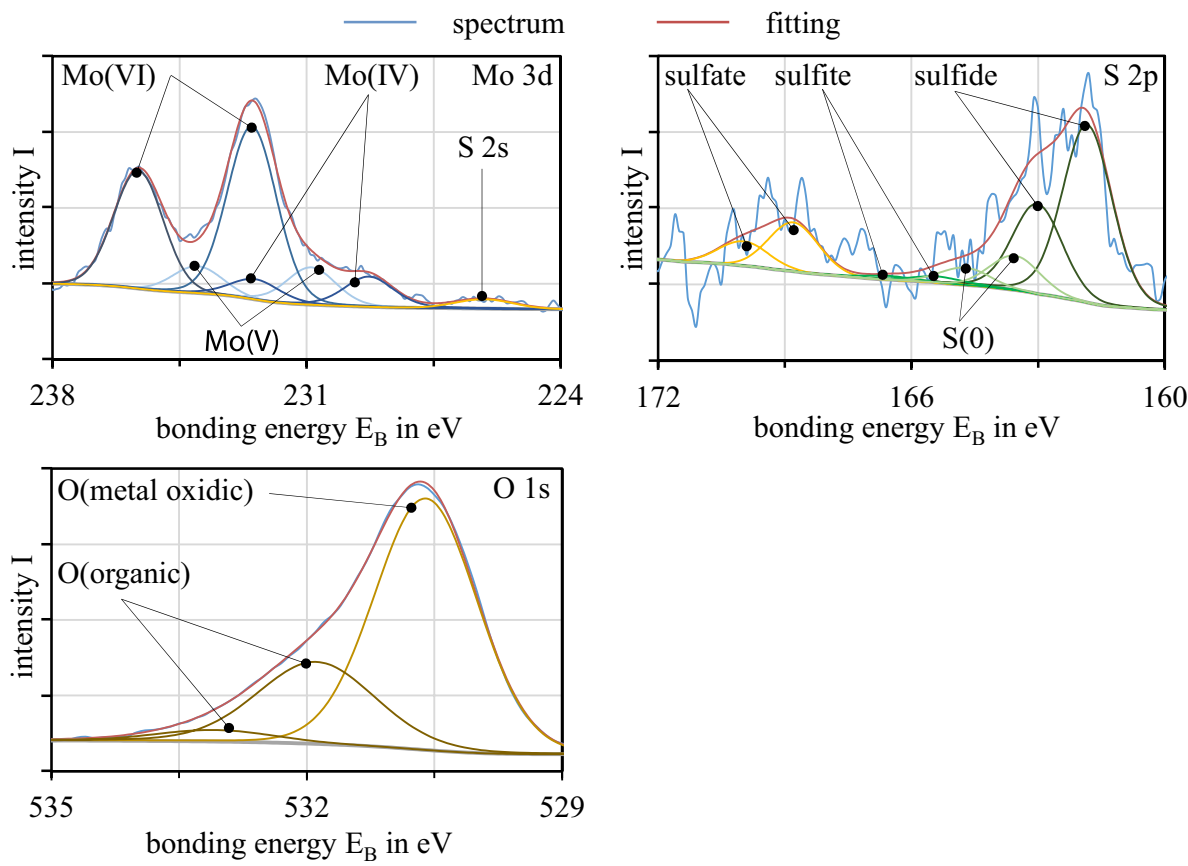

\begin{tabular}{|c|c|c|c|c|c|c|c|c|}
\hline \multirow[t]{2}{*}{ Information depth } & \multicolumn{2}{|c|}{ Mo (VI) } & \multicolumn{2}{|l|}{$\operatorname{Mo}(\mathrm{V})$} & \multicolumn{2}{|c|}{ Mo (IV) } & \multicolumn{2}{|c|}{ Mo (0) } \\
\hline & in at $\%$ & in $\%$ & in at $\%$ & in $\%$ & in at $\%$ & in $\%$ & in at $\%$ & in $\%$ \\
\hline Surface before sputtering & 0.4 & 64 & $<0.1$ & 7 & 0.2 & 29 & - & - \\
\hline$t=5$ min sputtering time & 2.9 & 71 & 0.6 & 15 & 0.6 & 14 & - & - \\
\hline$t=120$ min sputtering time & 1.3 & 25 & 1.4 & 28 & 2.4 & 47 & - & - \\
\hline
\end{tabular}

Bold values represent the percentage of the corresponding oxidation state of the element
Table 12 Quantification of Mo on the wear track on $100 \mathrm{Cr} 6$ counter part after tribological testing at $p_{\mathrm{H}}=1300 \mathrm{MPa}$ and $s=200 \mathrm{~m}$ 
Table 13 Quantification of S on the wear track on $100 \mathrm{Cr} 6$ counter part after tribological testing at $p_{\mathrm{H}}=1300 \mathrm{MPa}$ and $s=200 \mathrm{~m}$

\begin{tabular}{|c|c|c|c|c|c|c|c|c|}
\hline \multirow[t]{2}{*}{ Information depth } & \multicolumn{2}{|c|}{ Sulfide } & \multicolumn{2}{|l|}{$S(0)$} & \multicolumn{2}{|c|}{ Sulfate } & \multicolumn{2}{|l|}{ Sulfite } \\
\hline & in at $\%$ & in $\%$ & in at $\%$ & in $\%$ & in at $\%$ & in $\%$ & in at $\%$ & in $\%$ \\
\hline Surface before sputtering & - & - & - & - & - & - & - & - \\
\hline$t=5 \mathrm{~min}$ sputtering time & 1.9 & 57 & 0.6 & 19 & 0.7 & 22 & $<0.1$ & 2 \\
\hline$t=120 \mathrm{~min}$ sputtering time & 1.9 & 74 & 0.3 & 13 & 0.3 & 12 & $<0.1$ & 1 \\
\hline
\end{tabular}

Bold values represent the percentage of the corresponding oxidation state of the element
Table 14 XPS analysis of $\mathrm{O}$ on the wear track on $(\mathrm{Cr}, \mathrm{Al}) \mathrm{N}+\mathrm{Mo}: \mathrm{S}$ after tribological testing at $p_{\mathrm{H}}=1300 \mathrm{MPa}$ and $s=200 \mathrm{~m}$

\begin{tabular}{llllll}
\hline Information depth & \multicolumn{2}{l}{ O (metal oxide) } & & O (organic) \\
\cline { 2 - 3 } \cline { 5 - 6 } & in at $\%$ & in $\%$ & & in at $\%$ & in $\%$ \\
\hline Surface before sputtering & 1 & $\mathbf{1 1}$ & & 8,3 & $\mathbf{8 9}$ \\
$t=5$ min sputtering time & 13 & $\mathbf{6 2}$ & & 8 & $\mathbf{3 8}$ \\
$t=120$ min sputtering time & 26 & $\mathbf{7 5}$ & & 8,5 & $\mathbf{2 5}$ \\
\hline
\end{tabular}

Bold values represent the percentage of the corresponding oxidation state of the element

Nevertheless, the shares of metal oxide bindings are rising with increasing information depth as shown in Table 14. Thereby the shares of iron oxides are increasing due to the proximity to the surface of the $100 \mathrm{Cr} 6$ counter part. Thus, there are predominantly oxide bonds for all information depths, which dominate the chemical composition of the tribofilm. On the counter part sulfur and molybdenum with the same oxidation numbers like on the basic part could be detected, except of $\operatorname{Mo}(0)$. Therefore it can be assumed, that $\operatorname{Mo}(0)$ is released out of the toplayer of $(\mathrm{Cr}, \mathrm{Al}) \mathrm{N}+\mathrm{Mo}: \mathrm{S}$ and is bonded to $\mathrm{S}$ or $\mathrm{O}$ in consequence of the tribological load. However, the offer of $\mathrm{S}$ is limited by the share of $S(0)$ at the toplayer, whereby $\mathrm{O}$ is provided unlimited out of the atmosphere. An additional factor, could be the higher affinity of metallic molybdenum to oxygen compared to sulfur due to differences in the Gibbs free energy $\Delta G=\Delta H-\mathrm{T} \cdot \Delta \mathrm{S}$ of $\mathrm{MoO}_{2}$ and $\mathrm{MoS}_{2}$. A calculation is not possible, since the real flash temperature in the tribological contact was not determined.

Sulfur was found in an unbonded state inside the tribofilm with $19 \%$ after $t=5$ min sputtering time and $13 \%$ after $t=120 \mathrm{~min}$ sputtering time. The measurement proves the release and transfer of $\mathrm{S}(0)$ out of the toplayer of the graded coating by basically enabling the in situ formation of $\mathrm{MoS}_{2}$, sulfates and sulfites during the tribological contact.

The presence of organic bindings was attributed to contaminations while handling of the samples. Contamination due to alcoholic cleaning solvent was excluded, as the tribofilm would have been removed otherwise.

\subsection{Correlation of Tribological and Chemical Analysis}

A schematic illustration summarizing the findings of the supply mechanism of graded $(\mathrm{Cr}, \mathrm{Al}) \mathrm{N}+\mathrm{Mo}: \mathrm{S}$ and the transfer mechanism of the tribofilm are shown in Fig. 15. The tribological results prove a significant friction and wear reduction due to the application of graded $(\mathrm{Cr}, \mathrm{Al})$ $\mathrm{N}+\mathrm{Mo}: \mathrm{S}$ compared to the contact of uncoated steel in fluid-free friction regime at humid air. The friction and wear reducing effect was explained by a tribofilm formation out of the toplayer containing the solid lubricantforming elements Mo and S. The XPS measurements of the toplayer of the graded $(\mathrm{Cr}, \mathrm{Al}) \mathrm{N}+\mathrm{Mo}: \mathrm{S}$ coating demonstrate, that molybdenum and sulfur are available in
Fig. 15 Schematic illustration of the supply and transfer mechanism during the tribological contact in PoD tribometer

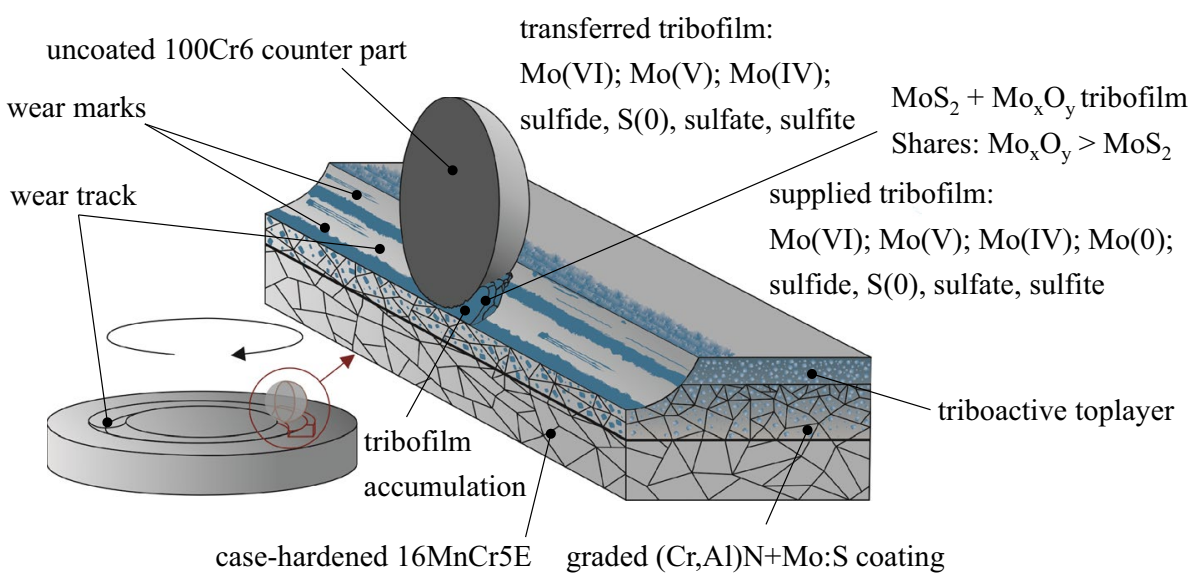


bonded state as $\mathrm{MoS}_{2}$ as well as in elemental state $\mathrm{Mo}(0)$ and $S(0)$. These elements are released from the toplayer into the tribological contact as a result of wear. Simultaneously, the tribological contact conditions enable the mechanical activation of the solid lubricant-forming elements Mo and S out of the triboactive coating. Hereby, the in situ formation of $\mathrm{MoS}_{2}$ and molybdenum oxide in the tribological contact is possible. In consequence of the high pressure between basic and counter part compared to the atmospheric pressure, particles of the tribofilm are pressed to the edge regions of the wear track or accumulate in front of the 100Cr6 counter part of the wear track. The tribofilm accumulation continuously provides $\mathrm{MoS}_{2}$ and molybdenum oxide during the tribological contact and is supplied by the toplayer of the graded $(\mathrm{Cr}, \mathrm{Al}) \mathrm{N}+\mathrm{Mo}: \mathrm{S}$ coating.

The combined analysis of Raman spectroscopy and XPS analysis proof the dominance of molybdenum oxides in favor of $\mathrm{MoS}_{2}$ in the chemical composition of the tribofilm. MoN seems to have a subordinate function in the tribofilm. Based on the results the bindings $\mathrm{MoO}_{3}, \mathrm{Mo}_{4} \mathrm{O}_{11}$, $\mathrm{MoO}_{2}$ and $\mathrm{Mo}_{x} \mathrm{O}_{y}$ as well as $\mathrm{MoS}_{2}$ were identified in the tribofilm. The higher share of $\mathrm{Mo}_{x} \mathrm{O}_{y}$ was attributed to the unlimited offer of $\mathrm{O}$ out of the atmosphere in the tribological contact as well as the Gibbs free energy of molybdenum oxide compared to $\mathrm{MoS}_{2}$. Furthermore, the share of sulfur is limited to the content in the toplayer of the graded $(\mathrm{Cr}, \mathrm{Al}) \mathrm{N}+\mathrm{Mo}: \mathrm{S}$ coating. In addition, iron oxides like $\gamma-\mathrm{FeOOH}, \alpha-\mathrm{FeOOH}, \mathrm{Fe}_{3} \mathrm{O}_{4}$, and $\alpha-\mathrm{Fe}_{2} \mathrm{O}_{3}$ as a result of wear of the uncoated $100 \mathrm{Cr} 6$ counter part were measured as well. Based on the Raman analysis it could be concluded that the different Hertzian pressure $p_{\mathrm{H}}=400 \mathrm{MPa}$ or $p_{\mathrm{H}}=1300 \mathrm{MPa}$ have no effect on the chemical compositions of the tribofilm.

\section{Summary and Conclusion}

In this study the supply mechanism of the self-lubricating triboactive graded $(\mathrm{Cr}, \mathrm{Al}) \mathrm{N}+\mathrm{Mo}: \mathrm{S}$ coating and transfer mechanism of the in situ build tribofilm under fluid-free friction regime at humid air was analyzed. Based on tribological analysis in a PoD tribometer the distribution and the chemical composition of the tribofilm were analyzed by means of Raman spectroscopy and XPS analysis. The result show:

- Significant wear and friction reduction through the application of graded $(\mathrm{Cr}, \mathrm{Al}) \mathrm{N}+\mathrm{Mo}: \mathrm{S}$ compared to uncoated steel/steel contacts under fluid-free friction regime

- Supply of elemental $M o(0)$ and $S(0)$ in the toplayer of graded $(\mathrm{Cr}, \mathrm{Al}) \mathrm{N}+\mathrm{Mo}$ :S enable the formation of different oxides, sulfides and sulfates
- Transferred Tribofilm accumulates in front of counter part provides molybdenum oxide bindings and $\mathrm{MoS}_{2}$

- Tribofilm is predominantly composed of molybdenum oxide in favor of $\mathrm{MoS}_{2}$

- Chemical composition of the tribofilm is independent of different Hertzian pressures

In the future, the development and analyses of a selflubricating triboactive $(\mathrm{Cr}, \mathrm{Al}) \mathrm{N}+\mathrm{Mo}: \mathrm{W}: \mathrm{S}$ coating will be conducted. Thereby the effect of the interaction between tungsten disulfide $\left(\mathrm{WS}_{2}\right)$, tungsten oxide $\left(\mathrm{W}_{\mathrm{c}} \mathrm{O}_{\mathrm{d}}\right), \mathrm{MoS}_{2}$ and $\mathrm{Mo}_{\mathrm{x}} \mathrm{O}_{\mathrm{y}}$ on the tribological contact under fluid-free friction regime will be analyzed. On the basis of these findings regarding the triboactive self-lubricating coatings a transfer to the application on gears in fluid-free friction regime is planned.

Acknowledgements The authors gratefully acknowledge the financial support of the German Research Foundation, Deutsche Forschungsgemeinschaft (DFG), within the project "Dry Lubrication of Spur GearsTribological Analysis and Constructive Design” BO 1979/66-1.

Author contributions KB: Conceptualization, Methodology, Resources, Writing-Review \& Editing, Supervision, Project administration, Funding acquisition. CK: Conceptualization, Methodology, Writing-Review \& Editing, Supervision; Project administration, Funding acquisition. MT: Conceptualization, Methodology, Investigation, Writing - Original Draft, Visualization.

Funding Open Access funding enabled and organized by Projekt DEAL. This study was funded by German Research Foundation, Deutsche Forschungsgemeinschaft (DFG), within the project "Dry Lubrication of Spur Gears-Tribological Analysis and Constructive Design” BO 1979/66-1.

Data availability The data that support the findings of this study are available from the corresponding author upon reasonable request.

Code availability Not applicable.

\section{Declarations}

Conflict of interest The authors declare that they have no known competing financial interests or personal relationships that could have appeared to influence the work reported in this paper.

Open Access This article is licensed under a Creative Commons Attribution 4.0 International License, which permits use, sharing, adaptation, distribution and reproduction in any medium or format, as long as you give appropriate credit to the original author(s) and the source, provide a link to the Creative Commons licence, and indicate if changes were made. The images or other third party material in this article are included in the article's Creative Commons licence, unless indicated otherwise in a credit line to the material. If material is not included in the article's Creative Commons licence and your intended use is not permitted by statutory regulation or exceeds the permitted use, you will need to obtain permission directly from the copyright holder. To view a copy of this licence, visit http://creativecommons.org/licenses/by/4.0/. 


\section{References}

1. Erdemir, A.: Solid Lubricants and Self-Lubricating Films. In: Bhushan, B. (ed.) Modern Tribology Handbook. Mechanics and Materials Science Series, pp. 787-826. CRC Press, Boca Raton, FL (2000)

2. Yilmaz, M., Kratzer, D., Lohner, T., Michaelis, K., Stahl, K.: A study on highly-loaded contacts under dry lubrication for gear applications. Tribol. Int. (2018). https://doi.org/10.1016/j.triboint. 2018.07.016

3. Hofmann, S., Yilmaz, M., Maier, E., Lohner, T., Stahl, K.: Friction and contact temperature in dry rolling-sliding contacts with MoS2-bonded and a-C:H: Zr DLC coatings. Int. J. Mech. Mater. Eng. (2021). https://doi.org/10.1186/s40712-021-00129-3

4. Gradt, T., Schneider, T.: Tribological performance of MoS2 coatings in various environments. Lubricants (2016). https://doi.org/ 10.3390/lubricants4030032

5. Wahl, K.J., Singer, I.L.: Quantification of a lubricant transfer process that enhances the sliding life of a MoS2 coating. Tribol. Lett (1995). https://doi.org/10.1007/BF00157976

6. Spalvins, T.: Lubrication with sputtered MoS2 films: principles, operation, and limitations. JMEP (1992). https://doi.org/10.1007/ BF02652388

7. Stupp, B.C.: Synergistic effects of metals co-sputtered with MoS2. Thin Solid Films (1981). https://doi.org/10.1016/0040-6090(81) 90023-7

8. Spalvins, T.: Frictional and morphological properties of AuMoS2 films sputtered from a compact target. Thin Solid Films (1984). https://doi.org/10.1016/0040-6090(84)90207-4

9. Simmonds, M.C., Savan, A., Pflüger, E., van Swygenhoven, H.: Mechanical and tribological performance of MoS2 co-sputtered composites. Surf. Coat. Technol. (2000). https://doi.org/10.1016/ S0257-8972(00)00521-1

10. Tedstone, A.A., Lewis, D.J., Hao, R., Mao, S.-M., Bellon, P., Averback, R.S., Warrens, C.P., West, K.R., Howard, P., Gaemers, S., Dillon, S.J., O’Brien, P.: Mechanical properties of molybdenum disulfide and the effect of doping: an in situ TEM study. ACS Appl. Mater. Interfaces (2015). https://doi.org/10. 1021/acsami.5b06055

11. Teer, D.G., Hampshire, J., Fox, V., Bellido-Gonzalez, V.: The tribological properties of MoS2/metal composite coatings deposited by closed field magnetron sputtering. Surf. Coat. Technol. (1997). https://doi.org/10.1016/S0257-8972(97) 00498-2

12. Teer, D.G.: New solid lubricant coatings. Wear (2001). https:// doi.org/10.1016/S0043-1648(01)00764-5

13. Kim, S.K., Ahn, Y.H., Kim, K.H.: MoS2-Ti composite coatings on tool steel by dc magnetron sputtering. Surf. Coat. Technol. (2003). https://doi.org/10.1016/S0257-8972(03)00181-6

14. Carrera, S., Salas, O., Moore, J.J., Woolverton, A., Sutter, E.: Performance of CrN/MoS2(Ti) coatings for high wear low friction applications. Surf. Coat. Technol. (2003). https://doi.org/ 10.1016/S0257-8972(02)00885-X

15. Ma, K.J., Chao, C.L., Liu, D.S., Chen, Y.T., Shieh, M.B.: Friction and wear behaviour of TiN/Au, TiN/MoS2 and TiN/ TiCN/a-C: H coatings. J. Mater. Process. Technol. (2002). https://doi.org/10.1016/S0924-0136(02)00123-1

16. Gilmore, R., Baker, M.A., Gibson, P.N., Gissler, W., Stoiber, M., Losbichler, P., Mitterer, C.: Low-friction TiN-MoS2 coatings produced by dc magnetron co-deposition. Surf. Coat. Technol. (1998). https://doi.org/10.1016/S0257-8972(98)00602-1

17. Strapasson, G., Badin, P.C., Soares, G.V., Machado, G., Figueroa, C.A., Hubler, R., Gasparin, A.L., Baumvol, I.J.R., Aguzzoli, C., Tentardini, E.K.: Structure, composition, and mechanical characterization of dc sputtered TiN-MoS2 nanocomposite thin films. Surf. Coat. Technol. (2011). https://doi. org/10.1016/j.surfcoat.2011.01.044

18. Kim, S.K., Cha, B.C.: Deposition of $\mathrm{CrN}-\mathrm{MoS} 2$ thin films by D.C. magnetron sputtering. Surf. Coat. Technol. (2004). https:// doi.org/10.1016/j.surfcoat.2004.08.013

19. Bae, Y.W., Lee, W.Y., Besmann, T.M., Yust, C.S., Blau, P.J.: Preparation and friction characteristics of self-lubricating TiNMoS2 composite coatings. Mater. Sci. Eng. A (1996). https:// doi.org/10.1016/0921-5093(95)10149-7

20. Erdemir, A.: A crystal-chemical approach to lubrication by solid oxides. Tribol. Lett. (2000). https://doi.org/10.1023/A:10191 83101329

21. Bobzin, K., Brögelmann, T., Kalscheuer, C., Thiex, M.: Selflubricating triboactive $(\mathrm{Cr}, \mathrm{Al}) \mathrm{N}+\mathrm{Mo}$ : $\mathrm{S}$ coatings for fluid-free applications. J. Mater. Sci. (2021). https://doi.org/10.1007/ s10853-021-06255-9

22. Scharf, T.W., Prasad, S.V.: Solid lubricants: a review. J. Mater. Sci. (2013). https://doi.org/10.1007/s10853-012-7038-2

23. Donnet, C., Martin, J.M., Le Mogne, T., Belin, M.: Super-low friction of MoS2 coatings in various environments. Tribol. Int (1996). https://doi.org/10.1016/0301-679X(95)00094-K

24. Kubart, T., Polcar, T., Kopecký, L., Novák, R., Nováková, D.: Temperature dependence of tribological properties of MoS2 and MoSe2 coatings. Surf. Coat. Technol. (2005). https://doi.org/10. 1016/j.surfcoat.2004.08.146

25. Khare, H.S., Burris, D.L.: The effects of environmental water and oxygen on the temperature-dependent friction of sputtered molybdenum disulfide. Tribol. Lett. (2013). https://doi.org/10. 1007/s11249-013-0233-8

26. Lince, J.R., Hilton, M.R., Bommannavar, A.S.: Oxygen substitution in sputter-deposited MoS2 films studied by extended X-ray absorption fine structure, X-ray photoelectron spectroscopy and X-ray diffraction. Surf. Coat. Technol. (1990). https://doi.org/ 10.1016/0257-8972(90)90008-Z

27. Fleischauer, P.D., Lince, J.R.: A comparison of oxidation and oxygen substitution in MoS2 solid film lubricants. Tribol. Int. (1999). https://doi.org/10.1016/S0301-679X(99)00088-2

28. Bobzin, K., Brögelmann, T., Kruppe, N.C., Hoffmann, D.C., Klocke, F., Mattfeld, P., Trauth, D., Hild, R.: Tribological studies on self-lubricating $(\mathrm{Cr}, \mathrm{Al}) \mathrm{N}+\mathrm{Mo}$ : $\mathrm{S}$ coatings at elevated temperature. Surf. Coat. Technol. (2018). https://doi.org/10. 1016/j.surfcoat.2018.06.067

29. Moulder, J.F., Chastain, J. (eds.): Handbook of X-Ray Photoelectron Spectroscopy A Reference Book of Standard Spectra for Identification and Interpretation of XPS Data. Perkin-Elmer Corporation, Eden Prairie, Minn (1992)

30. Dieterle, M., Mestl, G.: Raman spectroscopy of molybdenum oxides. Phys. Chem. Chem. Phys. (2002). https://doi.org/10. 1039/B107046K

31. Beattie, I.R., Gilson, T.R.: The single-crystal Raman spectra of nearly opaque materials. Iron(III) oxide and chromium(III) oxide. J. Chem. Soc. A (1970). https://doi.org/10.1039/J1970 0000980

32. Barshilia, H.C., Selvakumar, N., Deepthi, B., Rajam, K.S.: A comparative study of reactive direct current magnetron sputtered CrAlN and CrN coatings. Surf. Coat. Technol. (2006). https://doi.org/10.1016/j.surfcoat.2006.03.037

33. Soignard, E., Shebanova, O., McMillan, P.F.: Compressibility measurements and phonon spectra of hexagonal transition-metal nitrides at high pressure: $\varepsilon-\mathrm{TaN}, \delta-\mathrm{MoN}$, and Cr2N. Phys. Rev. B (2007). https://doi.org/10.1103/PhysRevB.75.014104

34. Testa-Anta, M., Ramos-Docampo, M.A., Comesaña-Hermo, M., Rivas-Murias, B., Salgueiriño, V.: Raman spectroscopy to unravel the magnetic properties of iron oxide nanocrystals for 
bio-related applications. Nanoscale Adv. (2019). https://doi.org/ 10.1039/c9na00064j

35. Windom, B.C., Sawyer, W.G., Hahn, D.W.: A Raman spectroscopic study of MoS2 and MoO3: applications to tribological systems. Tribol. Lett. (2011). https://doi.org/10.1007/ s11249-011-9774-x

36. de Faria, D.L.A., VenâncioSilva, S., de Oliveira, M.T.: Raman microspectroscopy of some iron oxides and oxyhydroxides. J. Raman Spectrosc. (1997). https://doi.org/10.1002/(SICI)10974555(199711)28:11\%3c873:AID-JRS177\%3e3.0.CO;2-B

37. Seguin, L., Figlarz, M., Cavagnat, R., Lassègues, J.-C.: Infrared and Raman spectra of $\mathrm{MoO} 3$ molybdenum trioxides and $\mathrm{MoO} 3$. xH2O molybdenum trioxide hydrates. Spectrochim. Acta Part A Mol. Biomol. Spectrosc. (1995). https://doi.org/10.1016/05848539(94)00247-9

38. Czichos, H., Habig, K.-H. (eds.): Tribologie-Handbuch. Tribometrie, Tribomaterialien, Tribotechnik, 4th edn. Springer, Wiesbaden (2015)

39. Chen, J.M., Wang, C.S.: Second order Raman spectrum of MoS2. Solid State Commun. (1974). https://doi.org/10.1016/ 0038-1098(74)90150-1
40. Barshilia, H.C., Rajam, K.S.: Raman spectroscopy studies on the thermal stability of TiN, CrN, TiAlN coatings and nanolayered TiN/CrN TiAlN/CrN multilayer coatings. J. Mater. Res. (2004). https://doi.org/10.1557/JMR.2004.0444

41. Jubb, A.M., Allen, H.C.: Vibrational spectroscopic characterization of hematite, maghemite, and magnetite thin films produced by vapor deposition. ACS Appl. Mater. Interfaces (2010). https://doi.org/10.1021/am1004943

42. Raillard, B., Rémond, J., Ramos-Moore, E., Souza, N., Gachot, C., Mücklich, F.: Wetting properties of steel surfaces modified by laser interference metallurgy. Adv. Eng. Mater. (2013). https://doi.org/10.1002/adem.201200247

43. Baltrusaitis, J., Mendoza-Sanchez, B., Fernandez, V., Veenstra, R., Dukstiene, N., Roberts, A., Fairley, N.: Generalized molybdenum oxide surface chemical state XPS determination via informed amorphous sample model. Appl. Surf. Sci. (2015). https://doi.org/10.1016/j.apsusc.2014.11.077

Publisher's Note Springer Nature remains neutral with regard to jurisdictional claims in published maps and institutional affiliations. 